\title{
Repatriation in practice:
}

\section{A critical analysis of the repatriation of human remains in New Zealand museums}

\author{
By Coralie O’Hara
}

A dissertation submitted to the Victoria University of Wellington in partial fulfilment of the requirements for the degree of Master of Museum and Heritage Studies

Victoria University of Wellington 


\begin{abstract}
The repatriation of human remains from museum collections is becoming increasingly common in museums around the world and particularly in New Zealand. Even the most amicable repatriation cases are complex, requiring a substantial commitment of time, energy and resources from museum staff involved in the negotiation process, to successfully overcome any issues that arise. Although it is known that the repatriation process can be challenging, the literature on the subject in museum studies and related fields focuses on the beneficial outcomes of successful negotiations, rather than explaining what difficulties can be encountered and how they can be solved.
\end{abstract}

This research asks how problems in the repatriation process can be overcome to create mutually rewarding relationships between museums and others involved in the repatriation of human remains. This problem was addressed through a case study of the Karanga Aotearoa Repatriation Programme at Te Papa and three examples of their work: the Natural History Museum in Rouen, France; the British Museum in London; and the Rangitāne o Wairau iwi in New Zealand. Documentary evidence relating to these three repatriation examples was reviewed and the insights of museum staff have been captured through interviews with professionals from Karanga Aotearoa, Auckland Museum and Tairāwhiti Museum in Gisborne. Together these methods provided data that presented a more detailed and rounded picture of the current New Zealand situation regarding the repatriation of human remains.

The dissertation concludes by assessing the difficulties in the practical repatriation process and how they have been overcome in New Zealand museums. I argue that repatriation practice, as an important area of museum practice in its own right, requires a flexible approach based on the principle of open-minded engagement with the perspectives of others involved in repatriation negotiations. This approach, focusing on relationships rather than transactions, is a marked departure from more traditional museum practice. 


\section{Acknowledgements}

I am sincerely grateful to all who made this dissertation possible and it is a pleasure to acknowledge them here. Firstly, I would like to offer my sincere gratitude to my principal supervisor Dr Conal McCarthy for his time, patience, advice, and encouragement throughout the dissertation process. This dissertation would also not have been possible without the support and input of my secondary supervisor Te Herekiekie Herewini, Manager of the Karanga Aotearoa Repatriation Programme.

I owe a debt of gratitude to the staff of the Karanga Aotearoa Repatriation Programme: Te Herekiekie Herewini, Amber Aranui, and Te Arikirangi Mamaku. Thank you for welcoming me in as an intern and for sharing your time and knowledge with me.

Thirdly, thank you to those who agreed to be interviewed. This dissertation simply would not have been possible without you and your insights. I deeply appreciate your willingness to share your experiences with me.

I am eternally grateful to my family and friends for believing in me and providing endless understanding and help especially in the final few months of writing. Diana Beeby and Chris de L'isle thank you very much for your help as proofreaders.

Finally, I would like to thank everyone in Victoria University's Museum and Heritage Studies programme especially Dr Lee Davidson, Annie Mercer, Anna Revington, Elspeth Hocking, Georgie Fell, Katrina McLennan, Nina Finigan, and Rebecca Loud for all your encouragement, support and friendship over the last two years. 


\section{Table of contents}

$\begin{array}{ll}\text { Introduction } & 1\end{array}$

Literature Review

Methodology

Outline 9

$\begin{array}{ll}\text { Chapter One - The New Zealand situation } & 10\end{array}$

$\begin{array}{ll}\text { The trade of kōiwi tangata } 1770-1988 & 10\end{array}$

$\begin{array}{ll}\text { Auckland Museum } & 17\end{array}$

The Museum of New Zealand Te Papa Tongarewa 22

$\begin{array}{ll}\text { Tairāwhiti Museum } & 25\end{array}$

$\begin{array}{ll}\text { Conclusion } & 27\end{array}$

$\begin{array}{lr}\text { Chapter Two - Repatriation case studies } & 28\end{array}$

$\begin{array}{ll}\text { The Karanga Aotearoa Repatriation Programme overview } & 28\end{array}$

$\begin{array}{ll}\text { Rangitāne o Wairau } & 30\end{array}$

Natural History Museum, Rouen $\quad 34$

$\begin{array}{ll}\text { British Museum, London } & 38\end{array}$

$\begin{array}{ll}\text { Conclusion } & 45\end{array}$

Chapter Three - Problems, solutions, and implications 46

Common challenges 46

The next big issues $\quad 52$

The importance of relationships

$\begin{array}{ll}\text { Museum practice } & 58\end{array}$

$\begin{array}{ll}\text { Conclusion } & 61\end{array}$

$\begin{array}{lr}\text { Conclusion } & 63\end{array}$

Appendix1: Glossary $\quad 68$

$\begin{array}{ll}\text { Appendix 2: Interview guide questions } & \mathbf{7 0}\end{array}$

$\begin{array}{ll}\text { References } & 71\end{array}$ 


\section{Introduction}

Repatriation has become a hot topic within the museums sector. From the late eighteenth century, museums around the world have actively collected, traded and displayed human remains (Fforde 2004, 1). In recent years, museums have reconsidered the ways in which they engage with the source communities from whom their collections originate. Part of this reconsideration has included questioning whether it is appropriate to continue to hold human remains, in light of the unsavoury history of their collection and strong opposition from source communities. While some museums resist repatriation on principle, growing numbers now respond positively to repatriation requests, seeing it as an ethical step that creates benefits for their institution.

Although repatriation is becoming more common, literature on it focuses on repatriation success stories, stressing the benefits that can result from repatriation. There is a lack of discussion of how museum professionals deal with repatriation in practice. The aim of this research is to further understanding of the repatriation process. I analyse the difficulties that can arise and how they are overcome, with reference to examples of repatriation negotiations and the insights of New Zealand museum professionals. In the literature review that follows, I discuss gaps in repatriation literature in more detail and examine the value of using New Zealand examples for a case study.

\section{Literature review}

McCarthy and Labrum $(2005,5)$ define museum studies as "the academic analysis of museum history, theory and practice, a critical examination of diverse aspects of museums within their social context". Museum studies draws on a range of related disciplines, such as Art History and Anthropology, making every aspect of the museum an object for study (McCarthy and Labrum 2005, 5). McCarthy and Labrum $(2005,4)$ explain that recently there has been an emphasis on studying museums from a theoretical framework, with little acknowledgement of the complex nature of practice. By focusing on the repatriation of human remains, this research deals with a particular aspect of current museum practice. 
Multiple authors mention that positive relationships with source communities can be formed through repatriation, resulting in benefits for a museum (see for example Hubert and Fforde 2002; Peers and Brown 2003; Peers 2003; Scott and Luby 2007, Hole 2007; Gabriel 2009; Wilson 2009). Benefits mentioned by Hole (2007), for example, are that museums obtain deeper interpretations of their collections and increase their relevance, and source communities are able to further their knowledge of objects and aspects of their cultures.

This emphasis on positive outcomes means that there are few examples of repatriation in practice, showing the steps of the repatriation process and what is required to eventually achieve these benefits and positive relationships. There is a limited amount of literature about repatriation process. Here I provide an overview of the literature that is available, drawing attention to gaps that exist.

Within museum studies, only Peers (2003) and Teague (2007) address practical aspects of the repatriation consultation process. Teague (2007) offers practical advice about things to consider during the consultation period. For example, she suggests that meeting organisers should choose meeting venues that conform to the physical needs of participants and should vary the location of meetings so that more people may be able to take part. However, these suggestions are not illustrated through a case study. In contrast, Peers (2003) offers a case study of the early stages of consultation between Pitt Rivers Museum, Oxford, and the Ojibwe community of Red Lake, Minnesota. Only the early stages of consultation could be discussed because the negative historical connotations of the museum collection in question caused the consultations to break down. In this case, Peers found the associations that hair samples in the collection had with racist and assimilative government policies were a barrier to discussing possibilities for collaborative work.

The basic processes of repatriation at the National Museum of Australia and The Museum of New Zealand Te Papa Tongarewa (Te Papa) have been described by Pickering (2010) and Hakaraia (2005) respectively. These sources describe the basic steps these institutions follow when negotiating the repatriation of human remains. Again, these descriptions are not discussed with reference to case studies. A gap remains for a detailed description of the repatriation process, addressing key issues such as how to overcome difficulties to establish beneficial partnerships. 
Potential difficulties in the repatriation of human remains are mentioned by Peers and Brown (2003), Hubert and Fforde (2002), Teague (2007) and Pickering (2010). Potential problems can relate to issues between groups negotiating repatriation or disagreements within one group. Another challenge is that in some cases a collection or a museum's history might have too many negative connotations for collaboration with a community to be possible (Peers and Brown 2003, 10). Peers $(2003,89)$ explains that consultation with source communities involves confronting histories and tensions that might be challenging to reconcile. Similarly, Hubert and Fforde $(2002,7)$ note that the repatriation of human remains can result in dissension rather than harmony with the source community. Although it is understood that such challenges are an inherent part of the repatriation process, Peers and Brown $(2003,10)$ argue that this focus has led to serious omissions in the literature. They explain that there are few writers who have commented on situations where insufficient resources, lack of planning, communication problems, or disagreements within the community have caused collaboration to fail. Although this is likely due to confidentiality, it means there is little discussion regarding any methodological, institutional or cross-cultural difficulties encountered during the process and even less on how to overcome such issues (Peers and Brown 2003, 10).

Even when source communities would like repatriation to occur, there are decisions they must make that can further complicate the process and mean that repatriation cannot occur within an institution's preferred time frame, such as a financial year (Pickering 2010, 170). Wilson $(2009,39)$ explains that negotiations surrounding locations, ceremonies and processes for reburial need to occur within the community and funds need to be found for this purpose. For example, Cubillo (2010, 25) discusses the difficulties the Ngarrindjeri people of the Lower Murray River, Lakes and Coorong region, South Australia, have experienced with repatriation. She explains that they currently have received, or are in the process of receiving, the remains of approximately 775 of their ancestors. To rebury their ancestors in their original resting places, they must first find financial and political support to secure their rights to the land, and until that is done, no reburial can occur.

Peers and Brown (2003) explain that despite the potentially mutually rewarding nature of relationships between museums and source communities, the process of establishing these relationships has received little attention in critical literature. In light of how positively museums describe these relationships, Scott and Luby (2007) conducted a survey of 
museums in the United States to examine their relationships with indigenous communities. They found that although museums consider these relationships important, they are not taking the necessary steps to ensure that they are long-lasting. They identify some of the reasons that relationships are neglected as a lack of policy on issues of concern to source communities, ineffective organisational structures, and no way of formalising knowledge about relationships when key staff leave.

Besterman (2006, 436), McCarthy (2011) and Peers and Brown (2003) note there are differences in the way that museums engage with source communities in European and postsettler countries. McCarthy $(2011,5)$ explains that the level of engagement between museums and source communities is more pronounced in post-settler nations because indigenous peoples are not distant in time and space. The extensive face-to-face contact necessary to build a relationship is less likely to occur between museums and overseas source communities because of obvious logistical issues and political distance (Peers and Brown 2003, 3-4). Peers and Brown $(2003,3)$ explain that European countries have been slower to adopt new attitudes to community involvement, whereas post-settler societies are more likely to find them necessary. They identify Australia, Canada, New Zealand and the United States as setting a standard for the new approach to relationships (Peers and Brown 2003, 3). This suggests that using a post-settler country, such as New Zealand, to investigate the repatriation of human remains would be particularly valuable.

Various authors identify New Zealand museums’ relationships with Māori as providing examples of successful relationships (see for instance Hubert and Fforde 2002; Peers and Brown 2002; Scott and Luby 2007; Hole 2006; Hole 2007). Scott and Luby (2007, 279) argue this success is a result of a dramatic change in Māori involvement in museums over the last twenty-five years in New Zealand, ensuring Māori participation in developing museum policy and procedures. Hole $(2006 ; 2007)$ argues that the repatriation of human remains in New Zealand is carried out in a cooperative and discreet manner, with Māori largely in control of the process, unlike in other countries where it attracts high publicity and debate. By looking at New Zealand museums more closely, it should be possible to observe the foundations of these successful partnerships.

Solomon (2005) has, for instance, described the development of the relationship between $\mathrm{Te}$ Papa and the Hokotehi Moriori Trust, an organisation that represents all Moriori people. 
Solomon $(2005,7)$ argues that this has been a mutually beneficial relationship and that for positive relationships like this one to develop, museums must see themselves as more than just curators of taonga (treasures) and human remains. ${ }^{1}$ According to Solomon (2005, 7), iwi (tribes) too must be willing to work in collaboration with museums. He explains that Te Papa is the only New Zealand museum that has invited Moriori participation in planning the exhibition of their taonga. Te Papa then provided staff to assist with the installation of a display of Moriori taonga from their collections at the opening of the Trust's Kopinga Marae (complex for gatherings and ceremonies). Te Papa has also indicated their willingness to assist with the development of a whare taonga (treasure house/museum) at the marae. Furthermore, Moriori have been involved in repatriations of Moriori human remains undertaken by Te Papa and are working towards their reburial on the Chatham Islands (Solomon 2005, 7).

In contrast to this successful relationship, Solomon (2005) describes problems in the relationship between the Hokotehi Moriori Trust and Auckland Museum. Moriori have been successful in negotiating the loan from Auckland Museum to Te Papa of Hatitimatangi, an important atua (god) stolen from a burial cave and then sold to the Auckland Museum (Solomon 2005, 6). However, since this loan, Auckland Museum staff have seemingly lost interest in the relationship. Solomon (2005) has hope that the relationship will again become positive. His experience contrasts with the conclusions of Hole $(2006 ; 2007)$ who argues that Auckland Museum is more successful than Te Papa at pursuing relationships and repatriation with source communities. Peers and Brown (2003), Solomon (2005), and Hole (2006; 2007) agree that the success of museums' repatriation programmes depends upon the museums' relationships with source communities. As Solomon's experience with Auckland Museum and Te Papa shows, the situation in which repatriation occurs in New Zealand can be complicated, but its success depends upon the quality of the relationships that underlie repatriation negotiations.

Although this study will be grounded in actual practice, Peers and Brown (2003) and Clifford (1997) offer two theories that can further understanding of the repatriation process. Firstly, Peers and Brown (2003) develop a theory of what the relationship between museums and their source communities should be like. According to Peers and Brown $(2003,2)$ source

\footnotetext{
${ }^{1}$ A glossary of Māori terms used follows in Appendix 1.
} 
communities have a legitimate stake in museum collections, with special needs and rights of access to this material. Thus, museums ought to act as stewards of collections on behalf of their originating community, under an ethical obligation for museums to involve people in decisions about their heritage (Peers and Brown 2003, 2). Because of this, Peers and Brown $(2003,8)$ advise that museums should put their agendas aside to address community members' concerns about human remains. Furthermore, museum staff should consider what their long-term goals for a relationship are, who sets these goals and who they will benefit (Peers and Brown 2003, 9).

Secondly, Clifford (1997) develops the idea of museums as "contact zones", providing another perspective on how museums should interact with various groups. The contact zone is a site in which people separated from each other historically or geographically can form ongoing relationships. According to this theory, museum collections create an "ongoing historical, political, moral relationship - a power-charged set of exchanges, of push and pull" (Clifford 1997, 192). Like Peers and Brown's concept of "source communities", seeing the museum as a contact zone will be useful for understanding the relationship between museums and source communities, and between museums and other institutions.

The literature on repatriation focuses on the benefits of repatriation, such as ongoing partnerships with source communities, meaning there are two important gaps in the repatriation literature. Firstly, there is little discussion of the problems that are inherent in the repatriation process, such as cross-cultural difficulties or the impact of a museum's negative image within the source community. Secondly, there is little information available that provides detailed and practical advice on how to form and maintain positive relationships with source communities and other institutions through repatriation. Several authors identify New Zealand museums' relationships with Māori as showing successful relationships. For this reason, it would be particularly interesting to examine the repatriation process in New Zealand, making use of Peers and Brown's (2003) and Clifford's (1997) theories about museum relationships. In the section that follows, I outline the methodologies used in undertaking this research. 


\section{Methodology}

Based upon the gaps in repatriation literature, my research aimed to answer the question, "How are problems in the repatriation process overcome to create mutually rewarding relationships between museums and others involved in the repatriation of human remains?" The methods of case study, interviews, and examination of documentary evidence were considered the best ones to help to answer this question.

As discussed in my literature review, New Zealand's repatriation practice is well-regarded, making New Zealand an ideal place to investigate the relationships and difficulties involved in the repatriation process. The Karanga Aotearoa Repatriation Programme, which operates out of Te Papa, has a government mandate to repatriate Māori and Moriori human remains from overseas to their iwi. Because of this mandate, Te Papa is the only museum in New Zealand that engages in both domestic and international repatriations and which has a dedicated team of professionals to oversee this work. For these reasons, I decided it would be best to use Karanga Aotearoa's work as the basis for an in depth case study. Additionally, during the course of the research, I worked as an intern with the Programme. This means that my understanding of repatriation practice is, in part, based on my personal observations and I have had access to unpublished files on specific repatriation cases, including meeting minutes and correspondence.

Within this case study, I focused on three examples of repatriations that Karanga Aotearoa has undertaken. I considered the way they handled repatriations with the British Museum in London and with the Natural History Museum in Rouen, France, as international examples of repatriation, and with the South Island iwi Rangitāne o Wairau as an example of domestic repatriation. These examples were chosen as they have been discussed in available literature and were undertaken by current Karanga Aotearoa staff.

To understand the experiences of staff involved in the repatriation process and to gather more information about the three repatriation examples within my case study, I interviewed the three staff from the Karanga Aotearoa Repatriation Programme, as well as key staff involved in the repatriation processes at Tairāwhiti Museum in Gisborne and at Auckland Museum. These six interviews were conducted to provide more context to current repatriation practice in New Zealand. 
To conduct these interviews, I used an interview guide approach. The interview guide is a list of questions to be explored during an interview (Patton 1990, 283). ${ }^{2}$ Within this guide, the interviewer is free to ask more questions to explore the subject, and so can build a conversational style with a focus on a predetermined subject (Patton 1990, 283). The advantages of this approach are that it allows for the best use of the limited time available for an interview, and makes interviewing across a number of people more systematic as it ensures that the same type of information is obtained from a number of interviewees (Patton 1990, 283). Furthermore, Patton $(1990,346)$ notes that quotations provide the raw data from an interview, so it is essential that the interviewee's actual words are captured. For this reason, interviews were recorded and transcribed. The transcripts were then analysed to find common themes shared by the staff of Karanga Aotearoa, Tairāwhiti Museum and Auckland Museum.

When doing research that involves participants, such as with interviews, the researcher has ethical responsibilities to those participants. It is the researcher's responsibility to ensure that the research will not cause any harm to participants and to end the research if it does prove harmful (Sarantakos 2005, 19). Additionally, researchers have responsibility over how participants' information is used and how they are portrayed when the research is published. Because of this, participants in my study were provided with an information sheet detailing the purpose and nature of the research, which people would have access to their data, and how they could resign from the research if desired. Participants were asked to sign an informed consent form agreeing to be part of the study. Following the interview, I sent participants a summary of their interview, allowing them to comment on it and clarify any points, and giving them an opportunity to remove themselves from the study if they so wished.

Finally, I reviewed documentary evidence relating to the New Zealand trade of human remains, repatriation practice at Auckland Museum, Te Papa and Tairāwhiti Museum, and the three repatriation examples of the British Museum, the Natural History Museum in Rouen and the negotiations with Rangitāne o Wairau. This documentary evidence came from diverse sources, including archives, Karanga Aotearoa's file notes, articles written by staff involved in repatriation at the above mentioned museums, and newspaper articles. Online

\footnotetext{
${ }^{2}$ The interview guide questions are provided in Appendix 2.
} 
resources included the British Museum's dossier on Karanga Aotearoa's claim, including all correspondence between the two, and the Wairau Bar Blog, which documented the return of human remains to Rangitāne o Wairau, covering the three months prior to repatriation until the completion of the reburial ceremony.

\section{Outline}

There is a need for a detailed study of repatriation practice explicitly addressing the difficulties that are inherent in the process and the nature of relationships with source communities. Using the Karanga Aotearoa Repatriation Programme as a case study and drawing on interviews with New Zealand museum professionals involved in repatriation and documentary evidence, my research aims to address this gap.

This dissertation is divided into three chapters. The first chapter provides background to the collection of Māori and Moriori human remains from the late eighteenth century. This history traces why museums in New Zealand and abroad have large collections of Māori and Moriori human remains and shows how three New Zealand museums are approaching their repatriation. The three museums - Auckland War Memorial Museum, Te Papa, and Tairāwhiti Museum - followed different approaches, each with its own challenges. The second chapter focuses on the government-mandated Karanga Aotearoa Repatriation Programme and their negotiations with the Natural History Museum in Rouen, the British Museum and the South Island iwi Rangitāne o Wairau. Chapter Three returns to my research question to analyse the difficulties that can arise in the repatriation process, how they are overcome, and what these answers mean for museum practice. This chapter draws heavily on my interview material and the lessons from the cases discussed in the first two chapters, showing how New Zealand museum professionals experience the repatriation process. 


\section{Chapter One-The New Zealand situation}

With regards to the repatriation of human remains, Auckland Museum's Collection Manager Laura Vodanovich, comments that, "It took years and years and years for museums to get to this place and it might take years and years and years for museums to get back out of it." "This place" refers to the situation New Zealand museums have found themselves in, where they have significant collections of Māori and Moriori human remains in their collections that they now wish to repatriate. Human remains are known in Māori as kōiwi tangata. ${ }^{3}$ This term includes both skeletal remains and preserved tattooed heads, called Toi moko. ${ }^{4}$ In this chapter, I expand upon how kōiwi tangata came to be in museums and institutions in New Zealand and overseas. This history will provide background to why the repatriation of kōiwi tangata is increasingly pursued. A number of museums in New Zealand have repatriation policies and are proactively repatriating kōiwi tangata to their iwi of origin. To show the diversity of approaches New Zealand museums use, I discuss how repatriations have been carried out at Auckland Museum, Tairāwhiti Museum in Gisborne and Te Papa. This information about current repatriation practice in New Zealand provides background and context to Te Papa's government-mandated Karanga Aotearoa Repatriation Programme, which is discussed further in Chapter Two.

\section{The trade of kōiwi tangata 1770 - 1988}

The collection and trade of kōiwi tangata was instrumental in the development of many New Zealand museums. During the late nineteenth and early twentieth centuries, the directors of some of the country's oldest and largest museums built up their collections through the trade of kōiwi tangata. They had sourced and removed the remains from their resting places, swapping them and other things such as moa bones with foreign institutions in exchange for items they desired but could not find in New Zealand. Although the foreign demand for kōiwi tangata decreased by the 1920s, New Zealand museums continued collecting them through donation, loan and purchase, with kōiwi tangata deposited in museums almost as a

\footnotetext{
${ }^{3}$ The Moriori term for human remains is koimi tangata. For ease of reference, in this dissertation I will use the Māori kōiwi tangata rather than both terms to refer to Māori and Moriori remains.

${ }^{4}$ Toi moko are also known as mokomokai, mokamokai, upoko tuhi and uru moko. The popular term mokomokai, is considered inappropriate by contemporary museum professionals as it translates to "slave's head" which is both offensive to the memory of the deceased and does not take account of the fact that the heads of friends and relatives were also preserved. I will use the term Toi moko following Pōmare (1993).
} 
matter of course if they were uncovered. The display and collection of the dead stopped in New Zealand in the 1970s and 1980s, but the large numbers of kōiwi tangata already in museum collections means that repatriation is an issue many museums face.

The trade in kōiwi tangata began almost as soon as the first Europeans visited New Zealand, with the first trade of a Toi moko occurring in 1770 during Cook's first voyage on the Endeavour. Joseph Banks, the naturalist onboard the Endeavour, bought the Toi moko of a young boy on 20 January 1770 at Queen Charlotte Sound in the South Island, in exchange for a pair of old linen drawers (see Robley 2003, 167; Te Awekotuku 2007, 48). The trade of Toi moko then flourished in the early nineteenth century, reaching its height during the Musket Wars (1818-1833). Besterman (2007, 14-15) distinguishes between three types of Toi moko - kin, foe, and trade, which are useful terms to explain why they were made and eventually sometimes sold. The role of each of these types in Māori society has been discussed by Besterman (2007), Hole (2007), Tapsell (2005), Jorgensen, (2005) and Robley (2003). The first type, kin Toi moko, were made by family or friends to remember a revered loved one or chief. Kin Toi moko were kept in secluded whare kōiwi (mausoleums), and wāhi tapu (sacred place/burial sites), and were brought out during events that required an ancestral presence. For instance, Toi moko would guard over bodies as they lay in state for upwards of five days during the funeral ritual, or tangihanga (Tapsell 2005, 155). The second type of Toi moko Besterman identifies, foe Toi moko, were the heads of enemies slain in battle, kept to taunt the enemy. They were subsequently returned during peacetime to cement peace between tribes. Tapsell $(2005,155)$ explains that when foe Toi moko were returned they would be "appropriately dressed, mourned over, then laid to rest in whare kōiwi, alongside the heads of other past leaders". The third category, trade Toi moko, includes foe Toi moko as well as Toi moko that were produced solely for trade during the early nineteenth century through the forced tattooing and murder of slaves.

As Jorgensen $(2005,7)$ notes, in the pre-European contact period, Toi moko were never intended for sale. There are two important factors that changed this situation. Firstly, the trade that developed could not have occurred without the European demand to possess Toi moko. Secondly, the Musket Wars created a type of inter-tribal arms race in which muskets were urgently required for self-defence and survival (Jorgensen 2005, 7). The easiest way to access the much-needed muskets was to sell Toi moko. Whereas a ton of dressed flax, which was laborious to make, could be traded for one musket only, selling one Toi moko netted 
multiple muskets and ammunition (Robley 2003, 138-139). Despite the high price that could have been attained for them, kin Toi moko were never sold by their communities (see Jorgensen 2005; Besterman 2008, 17; Besterman 2007; Hole 2006, 36; Hole 2007, 9). The only circumstance in which kin Toi moko were traded was if they had been raided from the whare kōiwi or wāhi tapu of an enemy's tribe (Hole 2007, 9). The Toi moko that were primarily traded included foe Toi moko and, once this supply was exhausted, Toi moko produced for trade. The sale of these Toi moko was not a light decision. Hole $(2007,9)$ states, "It was thus only in circumstances where a tribe feared that it could not defend itself without muskets, and where it was certain that it would never in future intend or need to make peace with the tribe from whom the heads had been taken, that it would trade those heads."

The trade in Toi moko began to decline in the late 1820s upon the deaths of two prominent traders, Pōmare and Hongi Hika (Te Awekotuku 2007, 49). The trade was then banned by Governor Darling of New South Wales in 1831, imposing a fine for those who continued the trade and requesting that individuals with Toi moko should return them to their families in New Zealand (Robley 2003, 179-180). Sales did continue after this, but only infrequently, as once the Musket Wars ended there was less need to sell enemies' heads. Furthermore, the art of tā moko (tattooing) had declined, owing to the real threat it posed to the lives of those with elaborate facial moko. As the open trade in Toi moko decreased, the trade of kōiwi tangata, including Toi moko, became the reserve of museums by the late nineteenth century.

Simpson $(2001,178-179)$ identifies three categories of collections of human remains. These are: archaeological collections of skeletal material, collections gathered for research into evolutionary theories and collections of ethnographic artefacts or "curiosities". According to Simpson (2001, 179), Toi moko fall into the "curiosities" category. In contrast, Māori and Moriori skeletal remains were collected through archaeology and for research into evolutionary theories. In the late nineteenth century, it was believed that different races could be identified by characteristics peculiar to each race. This theory was not proved by looking at individuals, prompting a belief that larger samples of human remains were needed to give a more accurate picture of the characteristics of each race (Fforde 2004, 35). In terms of sheer numbers collected, the trade of Māori and Moriori skeletal remains for this purpose was more extensive than the trade of Toi moko. For instance, currently there are approximately 500 kōiwi tangata held at Te Papa alone, with a similar number assumed to be still held overseas, 
and still more in other New Zealand museums (Herewini 2008, 405; Hole 2007, 15). This is in contrast to roughly 200 Toi moko that remain in museum collections (Herewini 2008, 405; Hole 2007, 15).

The first directors of New Zealand's three biggest museums in the nineteenth century, including Julius von Haast at Canterbury Museum, James Hector at the Colonial Museum in Wellington, and Thomas Cheeseman at the Auckland Museum, exploited the scientific interest in human remains. These directors led expeditions to collect kōiwi tangata, swapping them with international museum directors for items they wanted for their own museums. For example, Auckland Museum's Annual Report for 1877-1878 records that, “Arrangements have been made by the curator for interchanges with most of the principal European museums, and a considerable number of specimens in all branches of natural history have been specially collected for this purpose" (Auckland Museum 1878, 10, cited in Tapsell 2005, 158). Thomas Cheeseman, secretary and curator of the Museum between 1874 and 1923, offered a variety of flora, fauna, objects and human remains to foreign institutions (Gill 2010, 136). In exchange, Cheeseman received bird and mammal specimens that could not be found in New Zealand, exotic plants, and human remains from Europe (Gill 2010, 135). In addition to leading expeditions, these directors had contacts who would source kōiwi tangata for them to trade (Tapsell 2005, 159). For instance, Frederick Huth Meinertzhagen, whose personal collection of artefacts and kōiwi tangata is the largest individual Māori collection in the British Museum, sent kōiwi tangata to Haast at Canterbury Museum (British Museum Dossier 2007, 117 and 120; Aranui 2009). Between April and June 1876, Meinertzhagen sent Canterbury Museum five skeletons and thirteen crania provenanced to "the sandhills, East Coast, North Island", which were then forwarded to five European institutions in Italy, Sweden, Germany and Austria (Aranui 2009, 4). Some remains were not required for international exchange and were instead accessioned into the collections of these museums.

As discussed, the trade in Toi moko that had flourished in the early nineteenth century had all but disappeared within New Zealand by the time museums were being established in the mid to late nineteenth century. Because of this, it was almost impossible to purchase Toi moko for museum collections within New Zealand. As a result, there have been a small number of Toi moko in the collections of New Zealand museums (estimated at around ten in the 1930s), in contrast to the large numbers overseas (Hole 2006, 55). Robley $(2003,194)$ comments that it is curious that museums in New Zealand and Sydney have both the fewest and the "worst" 
quality Toi moko, despite historically being the major centres of their trade. However, since several hundred Toi moko had been traded in the past, the only way for New Zealand museum directors to get one was by purchasing it from a private collector or museum overseas. For instance, in the 1870s Haast negotiated with the Sydney Museum for a Toi moko without success, before enlisting the help of Walter Buller in England (Haast 1948, 633). Buller acquired one from a private collector, which arrived at the Museum in 1873 (Haast 1948, 633). Canterbury Museum had two Toi moko by 1896, one of which came via Cambridge in England and the other which had come from England having first left Taranaki in 1837 (Robley 2003, 199).

As it became increasingly clear that theories about racial characteristics would not be proved through large samples of human remains, the international demand for kōiwi tangata decreased and ultimately stopped from the 1920s (Fforde 2004, 40; Tapsell 2005, 162; Hole 2007, 10). However, New Zealand museums actually increased their collections of human remains at this time. Tapsell $(2005,162)$ explains this increase as being due to higher numbers of donations from the general public. By 1900, $83 \%$ of land belonged to the government or people of non-Māori descent, and kōiwi tangata often came into museum and university collections having been accidentally disturbed during building or other development work (Hole 2007, 13-14; King 2003, 258). When burials were disturbed, it was taken as a given that the remains would have scientific value and should be investigated. For instance, when Māori burial caves were discovered under Maungakiekie, One Tree Hill, in Auckland in 1907, Cheeseman was among the learned men who visited the cave and examined its kōiwi tangata (Taranaki Herald, 11 June 1907).

The collection and display of human remains has always been controversial in New Zealand. An incident with the aforementioned Toi moko sent from Buller to Haast demonstrates that controversy existed as early as the 1870s. Shortly after it arrived at Canterbury Museum, the Toi moko had its glass case covered with a cloth, following disapproval of its display, and it was subsequently only shown to interested people (Haast 1948, 633). This action was taken after the Attorney-General upheld a complaint about the Toi moko's display and said that unless it was removed from sight, Haast would be fined under Governor Darling's 1831 law (Robley 2003, 182). Comments made in correspondence between museum directors and their agents show they knew there would be opposition to their actions. For instance, in a letter to Haast, Meinertzhagen expressed regret that he could not send more kōiwi owing to the two 
hundred Māori living nearby, stating that he cannot "run counter their prejudices. You doubtless know how they respect the bones of their ancestors" (cited in Aranui 2009, 3-4). Throughout the 1900s, this controversy continued. In 1932, for example, a community took its concerns over the desecration of graveyards to the government, resulting in Sir Apirana Ngata, the Minister of Native Affairs, unsuccessfully asking Auckland Museum to stop excavating a graveyard (Tapsell 2005, 163). However, it was not until the 1980s that the situation changed significantly.

Through the twentieth century, the New Zealand Government was asked to become involved in restitution and repatriation cases on several occasions with varying results. On the first occasion, Horatio Gordon Robley offered his collection of thirty-five Toi moko to the New Zealand Government for $£ 1000$ in 1908 (Te Ara website). The offer was refused and thirty of them are now in the American Museum of Natural History, New York, which has the largest collection of Toi moko outside New Zealand (Te Ara website; Hole 2006, 55). The government was successful in securing the return from London of the Oldman Collection, which included Māori taonga and Toi moko as well as Polynesian artefacts. With encouragement from New Zealand museum professionals, in 1948 the government agreed to purchase the collection from William Oldman himself for $£ 44,000$ and to deposit it on loan in the major New Zealand museums (Neich and Davidson 2004, xviii). The government was actually unable to intervene in the case of the Andreas Reischek collection in Austria. The Reischek collection, which included New Zealand endangered native birds, taonga and human remains was taken from New Zealand to Austria in the 1880s and bought by the Imperial Natural History Museum in Vienna in 1890. When a book based on Reischek's diaries, written by his son, was translated into English in 1930, it confirmed his scurrilous collection methods, which included theft of kōiwi tangata in a conscious breach of trust and tapu (sacred restrictions). ${ }^{5}$ When the facts of this case were revealed, public outrage resulted. Following World War Two, it was suggested that the restitution of the entire Reischek collection should be made a condition of peace talks with Austria. This was the subject of two petitions being presented to the government in 1945 and 1946 respectively (Miscellaneous - Mummified bodies of Māori chiefs). Enquiries into the possibility of restitution were made by the government, but it was found that the claim could not be advanced because it was not a matter related to the war. The government again became

\footnotetext{
${ }^{5}$ This book was written by Reischek's son and published as Sterbende welt in 1924. Translated into English by H.E.L Priday, it is known as Yesterdays in Maoriland: New Zealand in the eighties.
} 
involved in this case in 1972 when, as Minister of Finance, Robert Muldoon visited Vienna and unsuccessfully investigated repatriation; and in 1974 when the Labour Government reexamined practices around indigenous cultural material. This re-examination resulted in objects being returned to their country of origin by diplomats who had removed them and prompted the Prime Minister, Norman Kirk, to ask the Ministry of Foreign Affairs to request the return of two "mummies", known as the "Kāwhia mummies", which were part of the Reischek collection. ${ }^{6}$ The return of one of the "mummies", the seventeenth century Tainui chief Tupahau, was agreed to providing that it was returned to an appropriate person for burial, in exchange for something, without publicity, and with assurance that the government would drop all claims to all other Reischek material. The negotiations again fell through. ${ }^{7}$ Tupahau's body was returned via the National Museum in 1985 although the government's role in this is unclear. ${ }^{8}$ This suggests that over the twentieth century there was a shift in the way repatriation was regarded by the government and New Zealand museums.

The last time a Toi moko came up for public sale was 1988. On this occasion, an Englishwoman, Nancy Weller-Poley, had found her grandchild playing with a Toi moko in her attic and decided to sell it through the London auction house Bonhams (Harrison 2002, 130). The planned sale caused outrage in New Zealand and was ultimately stopped through the efforts of Graham Latimer. Latimer gained legal guardianship of the Toi moko, now known as “Tupuna Māori” (Harrison 2002). Because of this, Tupuna Māori was withdrawn from the auction, but retained by Weller-Poley until a trade was negotiated in which she returned the Toi moko in exchange for a mere (greenstone weapon) (Harrison 2002, 135).

By 1988, when Tupuna Māori was almost auctioned by Bonhams, there had been a shift in New Zealand museums' attitudes towards Māori and displaying human remains so repatriation was already occurring. For instance, there was by then a wāhi tapu at the National Museum (now Te Papa) designed to hold unprovenanced kōiwi tangata which had been repatriated to New Zealand through the work of Māui Pōmare. This wāhi tapu was even

\footnotetext{
${ }^{6}$ Although generally known as "mummies" the preserved bodies would be better described as "dessicated" 7 Tupahau's body was eventually returned to his descendent the Māori Queen, Dame Te Atairangi Kaahu, in 1985 for reburial on Taupiri Mountain in the Waikato region. Tupahau's body was accompanied to New Zealand by the Director of the Museum fur Volkerkunde, Dr. Hanns Peter, and was taken to the National Museum to await overnight the arrival of Dame Te Atairangi Kaahu and a quiet return ceremony (Miscellaneous - Mummified bodies of Māori chiefs).

${ }^{8}$ The repatriation was agreed to providing there was as little publicity as possible and publically accessible government archives do not record events after 1975 (Miscellaneous - Mummified bodies of Māori chiefs).
} 
considered as a final resting place for Tupuna Māori before Latimer settled on reburial (Harrison 2002, 134). The 1980s can be seen as a turning point in museums' relationships with Māori and the incorporation of more Māori values into museum practice. The exhibition Te Māori, which toured the United States between 1984 and 1986 before being shown in New Zealand, is generally credited with causing this shift, as it raised interest in taonga and mātauranga Māori (traditional knowledge). It was during this decade that, according to Tapsell (2005, 153-154), Māori successfully challenged the "civilised" practice of displaying kōiwi tangata and New Zealand museums began to acknowledge that authority for indigenous human remains belongs with descendants rather than museums. With this change in value system, repatriation has become an issue many museums in New Zealand have to address because of the large number of kōiwi tangata they had previously collected (see also McCarthy 2011; Butts 2003).

\section{Auckland Museum}

Auckland Museum is one of New Zealand's largest and oldest museums. The Museum began humbly in 1852, in a two-roomed farmhouse in central Auckland (Auckland War Memorial Museum website, History of the Museum). As its collections grew, the Museum moved sites, occupying a further three sites in central Auckland before moving into its current War Memorial building in 1929. One of the primary ways in which the Museum's collections were added to was through the collection and exchange of human remains. As Tapsell $(2005,158)$ explains, Auckland Museum is located in the most densely Māoripopulated region of New Zealand and next to the country's largest seaport, meaning there was ample opportunity to locate kōiwi tangata and trade them internationally.

Auckland Museum curator Thomas Cheeseman understood the opportunity he had to trade items from New Zealand that foreign institutions might lack in exchange for things they did not need but which were rare in New Zealand. Because of the scientific interest in racial types, there was a significant demand for kōiwi tangata. Cheeseman had a network of agents who would find kōiwi tangata for him and help him to ship them to museums in the United States, the United Kingdom and Europe. Rather than being one-off exchanges, the trade relationships he established continued over a number of years. For instance, between 1877 and 1904, Cheeseman is known to have received hundreds of bird, mammal, insects and plant specimens and an Egyptian mummy from the Florence Natural History Museum in exchange 
for ethnographic items, 150 bird specimens, approximately six hundred plants and fifteen Māori crania (Gill 2010, 133). Those human remains that were not required for such exchanges were accessioned into the Museum's collection (Tapsell 2005, 160). During the forty years prior to Cheeseman's death in 1924, Auckland Museum had accessioned 145 human remains into their collection (Tapsell 2005, 162).

From the 1920s Auckland Museum's accessioning of kōiwi tangata accelerated. For instance, the Museum accessioned fifty-five human remains into their collection in 1928 alone (Tapsell 2005, 162). Tapsell $(2005,162)$ argues that this was due to increased donations from members of the public who had found kōiwi tangata; or from the police when they undertook investigations of formerly secret Māori burial grounds. For example, after Ngāti Whātua o Orākei were evicted from their marae in 1951, police were required to investigate when burial grounds on their land were discovered to ensure that the remains were pre-European contact (Tapsell 2005, 164-165). When the investigations were complete, the police usually passed the remains to either the Auckland Museum or the University of Auckland's Anthropology Department, whose collection was itself eventually deposited in Auckland Museum on loan (Tapsell 2005, 165).

Vodanovich (2011) believes Auckland Museum's last acquisition of human remains was in the early 1990s. From its founding until this last acquisition, the Museum's collection of kōiwi tangata was extensive. Auckland Museum's human remains database includes 1317 human remains from various countries (Hole 2006, 61). ${ }^{9}$

According to McCarthy $(2011,160)$ the Museum increasingly had Māori input in conservation, the redevelopment of displays, and public programmes from the 1970s and 1980s. However, the repatriation of Auckland Museum's human remains collection was eventually made possible through changes to the Museum's relationships with Māori in the 1990s. Tapsell (2005, 166-167) explains changes to the Museum's governance in 1996, which gave Māori more involvement in the Museum's operations. Ngāti Whātua o Orākei had land and the title to their marae returned to them in 1991, which prompted the Museum to recognise Ngāti Whātua customary rights in their updated legislation of 1996. This legislation created a position for a Māori representative on the Museum's ten member Trust

\footnotetext{
${ }^{9}$ Some of this number will have since been repatriated to their iwi.
} 
Board and established the Taumata-a-Iwi Māori advisory committee, comprising three members from Ngāti Whātua o Orākei and one representative from each of the two neighbouring tribes Tainui and Ngāti Paoa. With these changes, the Museum came to consider the repatriation of the human remains. One of the first actions taken on this front was to move all human remains from the Ethnology Store to a special consecrated store in 2001.

At the time when the remains were moved, Auckland Museum had already begun to repatriate kōiwi tangata to iwi. McCarthy $(2011,160)$ notes that a collaboration between Auckland Museum and Ngā Puhi, which aimed to provide information about the Ngā Puhi taonga in the Museum, resulted in the repatriation of all Ngā Puhi kōiwi tangata from the Museum. The kōiwi tangata repatriations to Ngā Puhi were completed in 1999 with the return of two Toi moko, the story of which shows how attitudes to the display of human remains and their repatriation have changed (Gregory 1999). The Toi moko were known to be the chiefs Moetarau and Koukou, who had died in battle in 1837 (Robley 2003, 194-195; Gregory 1999). They were stolen from a burial cave in the 1840s and recognised by relatives in an Auckland curio shop in the 1850s, from where they were sold to a ship's captain who took them to England (Robley 2003, 194; Gregory 1999). There they made their way into a private collection and were eventually exchanged with Auckland Museum for two Moriori crania (Robley 2003, 194; Gregory 1999). ${ }^{10}$ These, and another two Toi moko in the Museum's collection, were displayed until 1951 (Gregory 1999; McCarthy 2011, 28). McCarthy $(2011$, 27-28) recounts the horror Māori visitors to the Museum felt upon seeing them in the 1930s and 1940s, which prompted a request for them to be removed from display. The repatriation of the two Ngā Puhi Toi moko was first formally requested in 1989 by the Whatitiri Trust, at which time the Museum asked that the Trust get the approval of all hapu (sub-tribes) descended from the chiefs (Gregory 1999). This approval was received, although

\footnotetext{
${ }^{10}$ Robley $(2003,195)$ says the Toi moko were in the collection of Dr Barnett Davis of London but were sold in around 1880 to an unidentified purchaser who then traded them with Auckland Museum for the two crania. Gregory (1999) reports that to attain the two Toi moko Auckland Museum traded the two crania with the London Royal School of Medicine. If both Robley and Gregory are correct then it would appear the toi moko went from Barnett Davis's collection to the London Royal School of Medicine, before returning to Auckland. However, a likely alternative is that Robley wrongly attributed the name Dr Barnett Davis to Dr Joseph Barnard Davis, a prominent collector of human remains, including Toi moko. Dr Joseph Barnard Davis's collection was purchased by the Royal College of Surgeons in 1880. For more on Dr Joseph Barnard Davis and his collection see Besterman (2005) and Davis (1867).
} 
this process took until 1998 to complete (Gregory 1999). ${ }^{11}$ Despite these returns, Auckland Museum's broad repatriation project did not properly begin until the development of the Ko Tawa exhibition from 2001.

The Ko Tawa exhibition offered the Museum the chance to really engage with the question of repatriation on a large scale (Tapsell 2011). Ko Tawa, which opened in 2005 and then travelled around New Zealand, exhibited twenty-eight taonga from the Museum's Gilbert Mair collection (Auckland War Memorial Museum website, Ko Tawa). In the process of preparing for the exhibition, Museum staff went to communities to research the taonga and ask for their participation. In doing this, staff knew they would receive questions (Tapsell 2011). These questions fell into three categories, including, "Will this help bring our children home?" "Can these taonga come back to our marae?" and "What else can you bring back? Do we have human remains in your museum?" (Tapsell 2011). Knowing that these questions would arise, staff did not begin their research with communities until they had prepared responses to each of these questions.

Before going to the communities, Museum staff prepared for these questions and the subsequent repatriations in three ways. Firstly, in 2001, Cressida Fforde was contracted to establish a human remains database. Fforde created an electronic file centralising all records for each kōiwi, resulting in provenance being established in 90\% of cases (Hole 2006, 61; Tapsell 2005, 167; Thompson 2006). Prior to this work beginning, the Museum was aware of the provenance details for only between $20 \%$ and $30 \%$ of the collection (Tapsell 2011). Preparing this database meant that Museum staff would be able to tell people exactly what remains they had from their community. Following this, Rangiiria Hedley was hired to engage with the communities and to negotiate repatriations (Tapsell 2011). Thirdly, the human remains were formally deaccessioned. All but $3 \%$ of the human remains at Auckland Museum have now been deaccessioned (Vodanovich 2011). With those 3\% there are difficulties such as paper records existing for the human remains, but the remains themselves cannot be found (Vodanovich 2011).

\footnotetext{
${ }^{11}$ It is surprising that the Toi moko were not returned sooner, as they were recognised named individuals. Robley (2003, 178-179) recounts the story of the revenge taken against Joe Rowe in January 1831 for refusing to return two Toi moko to their relatives. When the heads of two Taupo chiefs were recognised by their relatives in Rowe's Kapiti curiosity shop their return was requested, but declined by Rowe with a laugh. In retaliation for this decision, later, when out on a boat, Rowe and his four sailors were attacked. Rowe and two of his sailors were killed, and two of their heads preserved (the other was "too badly chopped about to be worth preserving").
} 
A number of human remains at the Museum are on loan or deposit. In these cases, the Museum contacts the individual who donated or loaned the remains to let them know they will be repatriated, without requesting their approval (Vodanovich 2011). In only two cases, people have contacted Vodanovich, the first to say they agree with what is being done and the second to argue against it (Vodanovich 2011). In cases where the donor is an institution, the Museum liaises with them to decide whether the Museum will take control over the repatriation or if they will proceed together (Vodanovich 2011). It has been difficult to get such institutions to make decisions on this front, possibly because non-museum institutions have had less experience with repatriation and therefore require more time to consider it (Vodanovich 2011). While Vodanovich organised contact with these institutions and individuals, Rangiiria Hedley would engage directly with the communities. Hedley would then contact Vodanovich to let her know that a repatriation would be taking place, and she and her team would prepare the remains for return (Vodanovich 2011).

Although each repatriation is different, there are two broad ways in which human remains have been returned to iwi. In some cases, the iwi that the human remains were being returned to came to the Museum to collect the human remains themselves. In the second category, Museum staff returned them with Ngāti Whātua officials, making it a tribe-to-tribe handover (Tapsell 2011). In these cases, sometimes the kōiwi would be taken straight to the urupā (cemetery) for reburial, followed by participants going to the marae, or alternatively the kōiwi and participants would go to the marae first and then on to the urupā (Tapsell 2011).

Originally, expectations were that the majority of repatriations would be completed by the end of 2006 with all of them finished by mid-2007 (Tapsell 2005, 168; Thompson 2006). These targets were over-ambitious and were revised. Instead, 2008 became the programmed year to complete up to $80 \%$ of the repatriations (Tapsell 2011). However, this too was not possible. In part, these targets were not achieved owing to upheaval for the project upon the appointment of a new director at the Museum in 2008, which resulted in restructuring and job losses for some of the project's key staff. Additionally, Vodanovich (2011) explains that there was an underestimation of the time and energy involved in the returns, which meant the targets were optimistic. So far, Auckland Museum has managed to return comparatively few of the kōiwi tangata in their collection although they are continuing with repatriations (Vodanovich 2011). 


\section{Te Papa}

Te Papa first began as the Colonial Museum in Wellington in 1865, changing its name to the Dominion Museum in 1907, before becoming the National Museum in 1972. The Museum rebranded itself as the Museum of New Zealand Te Papa Tongarewa (Te Papa) in 1998 following the Museum of New Zealand Te Papa Tongarewa Act 1992 (Te Papa website, Our history). Through the Act, Te Papa was founded with a bi-cultural policy enshrined into its legislation and vision. It was the predecessors of Te Papa that established the collection of human remains and began the efforts to repatriate them.

The acquisition of kōiwi tangata by Te Papa's predecessors followed the same general trend as Auckland Museum. Like Cheeseman at Auckland Museum, in the late nineteenth and early twentieth centuries, the directors of the Colonial and Dominion Museums, James Hector and Augustus Hamilton, supplied the international trade of human remains, exchanging them with foreign institutions and keeping some for themselves. The Museum also added to its collection through donation or purchase. For instance, the Dominion Museum acquired two kōiwi tangata from the Wairau Bar, the first through purchase in 1939 and the second through donation from the Ministry of Māori Affairs Te Puni Kōkiri (Karanga Aotearoa Repatriation Programme 2009a). Like other museums, the Dominion and National Museums continued to display kōiwi tangata through much of the twentieth century. For instance, in the 1960s four Toi moko were still displayed at the Dominion Museum (McCarthy 2007, 107). Te Papa eventually inherited the kōiwi tangata collection, although work had already begun to repatriate the kōiwi tangata long before Te Papa opened.

The first repatriation the National Museum conducted was to Hawke's Bay via Napier Museum in 1958 (Te Papa website, Domestic repatriations). However, it was Māui Pōmare's work from the 1970s repatriating kōiwi tangata, especially Toi moko, that prompted the National Museum to address repatriation of the collection on a large scale (Karanga Aotearoa Repatriation Programme 2009b, 2; McCarthy 2011, 41; Tapsell 1998, 207). Pōmare was the Chair of the National Museum Council and it was through his work that the National Museum became the national repository for kōiwi tangata (Karanga Aotearoa Repatriation Programme 2009b). Pōmare established a wāhi tapu for the kōiwi tangata, allowing them to be held away from other collection items (Hakaraia 2005). This wāhi tapu was able to hold unprovenanced kōiwi tangata through having the spiritual protection of the Museum's local 
iwi, Te Āti Awa (Tapsell 1998, 148). It is this factor that has allowed the Museum to receive unprovenanced human remains from overseas (Tapsell 1998, 148; Hole 2007, 18).

Additionally, Pōmare collected information and research on the kōiwi tangata that had been repatriated (Hakaraia 2005). While Pōmare was the Chair of the National Museum, he brought the remains of thirty-seven ancestors back to New Zealand (Karanga Aotearoa Repatriation Programme 2009b, 2).

Throughout the 1990s, Pōmare's work was continued by his relative Dalvanius Prime and by the National Museum (which became Te Papa in 1998). During the 1990s, the National Museum and Te Papa returned kōiwi tangata to iwi in the South Island, Ngāi Tai, Tairāwhiti and Rongowhakaata (Te Papa website, Domestic repatriations). Additionally, kōiwi tangata were returned to New Zealand from museums in Australia, Sweden, Switzerland, England, Denmark and Scotland (Te Papa website, International repatriations).

Although successful in many instances, Pōmare and the National Museum's approach to repatriation was not without its problems. Its shortcomings were particularly noticeable in the previously described case of the auction of Tupuna Māori in London in 1988. Harrison (2002, 130-131) describes the approach of the National Museum to this case and why it was ineffective:

The Board of the National Museum (Latimer was a member) could do nothing. Its policy was to negotiate quietly, without publicity, for the return of artifacts and human remains from overseas collections, public and private. Persuasion, through appeals to good-will and human decency, was its preferred method. It never offered money: that would increase the value of the artifacts as commercial products. Nor did it have the resources needed to take legal action. This policy resulted in a slow, mostly invisible, recovery process involving museums, friendly diplomats, long-term loans, and promises that anything recovered would be made available for study, or future research, if needed. Feelers, proposals, were always made delicately so museums did not feel exposed to greater demands for the return of stolen or doubtfully acquired treasures from other countries, other peoples.

In the urgent negotiations for the return of the Toi moko, beginning only sixteen days before the auction was scheduled, the National Museum lacked sway, authority or resources, meaning it had no ability to help to progress the case. Pōmare's efforts to repatriate kōiwi tangata and the relationships he established form the basis of Te Papa's current repatriation programme. However, important changes have been made to develop the programme and 
take account of its shortcomings. Significant changes were ultimately made following a series of wānanga (seminars) in the late 1990s, which gave support for Te Papa's ongoing repatriation programme and allowed it to be resourced properly.

In 1998 and in 1999, two wānanga were held between iwi representatives, Te Papa and the Ministry of Māori Development Te Puni Kōkiri, which highlighted the importance of involving Māori and Moriori in repatriation and suggested that there ought to be one organisation that leads the repatriation process with facilitation and funding from the government (Karanga Aotearoa Repatriation Programme 2009b, 2-3). Te Papa was considered to be the most appropriate organisation to lead the repatriation process on behalf of Māori and Moriori (Karanga Aotearoa Repatriation Programme 2009b, 2). Following these wānanga, in 2003 the New Zealand Government agreed to mandate Te Papa as the Crown's agent to repatriate kōiwi tangata. The mandate acknowledges that the return of kōiwi tangata is a significant issue for Māori, who regard kōiwi tangata as being taonga protected under the Treaty of Waitangi (Cabinet Policy Committee 2003, 2).

Six principles guide the government mandate. Firstly, the government's role is one of facilitation; it does not claim ownership of kōiwi tangata. Secondly, repatriation is only by mutual agreement. Thirdly, the programme does not cover Māori or Moriori remains in war graves. Fourth, kōiwi tangata must be identified as coming from New Zealand or the Chatham Islands. Fifth, Māori and Moriori are to be involved in the repatriation process and are to determine the final resting place. Finally, no payment is to be made for kōiwi tangata (Cabinet Policy Committee 2003, 3-4). Additionally, the mandate required that Te Papa create a "Recognised Expert/Kaumatua Group" to provide advice and support to the programme (Cabinet Policy Committee 2003, 4). This group, now known as the Repatriation Advisory Panel, provides knowledge on iwi, repatriation and tikanga (customs) to the Te Papa team that carries out this mandate, which is named the Karanga Aotearoa Repatriation Programme (Hakaraia 2005).

The six mandate principles are reminiscent of the approach described by Harrison (2002, 130-131), which he thought ineffective. However, the major constraints in the case he described came from the Museum's lack of authority and resources, which the government mandate redresses significantly. The mandate specifically recognises that although Te Papa had been undertaking repatriation work systematically since the mid-1980s, they had been 
constrained by not having formal government approval to undertake the work and sought to remedy this situation (Cabinet Policy Committee 2003, 2). Other differences between the approach Harrison describes and Karanga Aotearoa's approach include that long-term loans are no longer accepted and repatriated kōiwi tangata are not made available for future research. The decision on final resting places is left to iwi to decide once the provenance of repatriated kōiwi tangata has been established. Although it is possible that iwi will decide to make provisions for future access, Karanga Aotearoa cannot guarantee this and so cannot make it a requirement of repatriation. Likewise, because it would prevent unconditional returns to iwi, which is their ultimate goal, Karanga Aotearoa does not accept long-term loan of kōiwi tangata.

The Karanga Aotearoa Repatriation Programme undertakes scoping research to identify Māori and Moriori remains in overseas institutions, negotiates repatriation with iwi and foreign institutions, and conducts physical repatriations to New Zealand and the return of kōiwi tangata to their final resting places (Herewini 2008, 405). In addition to following the principles of their mandate, the Karanga Aotearoa team follows guidelines in Te Papa's kōiwi tangata policy. The policy ensures that kōiwi tangata are appropriately cared for, with stipulations that kōiwi tangata will be registered for identification and will be kept in wāhi tapu, access to which is strictly governed. Te Papa now maintains two wāhi tapu - one at its main Cable Street site and the second at its Tory Street research and collections facility. Since 2004, the Programme has repatriated kōiwi tangata from fourteen countries (Karanga Aotearoa Repatriation Programme 2012, 4). Estimates are that there are still up to five hundred kōiwi tangata held in overseas collections, in addition to approximately five hundred kōiwi tangata and over one hundred Toi moko already held in Te Papa's wāhi tapu (Herewini 2008, 405; Hole 2007, 15; Hole 2006, 55; Karanga Aotearoa Repatriation Programme 2009b, 2; Hunt 2012; Karanga Aotearoa Repatriation Programme 2012, 4).

\section{Tairāwhiti Museum}

Tairāwhiti Museum took quite a different approach to the formalised and large-scale approaches of Te Papa and Auckland Museum. From its establishment in 1954 as the Gisborne Museum and Arts Centre, until the 1970s, when the Museum stopped accepting them, kōiwi tangata were brought into the Museum by people who had discovered them, usually as a result of building developments in the area (Butts 2003, 235; Wyllie 2011). As a 
result, Tairāwhiti Museum had the kōiwi tangata of approximately fifteen individuals when they began to consider repatriation in 2005 (Wylie 2011).

Butts (2003) traces the increasing involvement of Māori in Tairāwhiti Museum and argues that two of the Museum's directors, Leo Fowler and Mike Spedding, were particularly instrumental in furthering Māori involvement at governance level. During Spedding's directorship (1997-2005), the Museum made significant changes to its governance structure and brand, which eventually allowed the repatriation of all kōiwi tangata in the collection (see Butts 2003 and McCarthy 2011). In 2000, the Gisborne Museum and Arts Centre changed its name to Tairāwhiti Museum to reflect its values and place in the wider Tairāwhiti region, of which Gisborne is a part (Butts 2003, 266). At the same time, an eleven-member trust board was established, including a representative from each of the five major iwi of the Tairāwhiti region, as well as representatives from the Gisborne District Council and Museum members (McCarthy 2011, 162; Butts 2003; 265). This board quickly began drafting new policies. Among these policies, the Kōiwi Tangata Policy, which was approved in July 2000, was created to facilitate the repatriation of the small number of kōiwi held by the Museum (Butts 2003, 267). According to this policy, which applies to remains of all ethnic groups, the Museum does not consider the human remains it holds to be part of its collection and will not collect more (Butts 2003, 267-268).

Although the Kōiwi Tangata policy had been approved in 2000, it was not for another five years that there were active attempts to repatriate the kōiwi tangata from the collection. Repatriation was finally prompted by the appointment of Jody Wyllie as Kaitiaki Māori, Curator Taonga Māori and Research Manager in 2005. While familiarising himself with the Museum's collections, Wyllie found the kōiwi tangata stored in banana boxes, setting off a chain of events that ended with him personally reburying them two years later (Wyllie 2011; McCarthy 2011, 172).

Upon finding the remains, Wyllie went to the Museum's board to ask about their presence in the collection and was informed that his first job would be to repatriate them all. With encouragement from two board members, Wyllie began to investigate repatriation, but found it extremely difficult to find people who were willing to discuss the issue or help him on a practical level (Wyllie 2011; McCarthy 2011, 172). Eventually, Wyllie met with a matakite, a Māori seer or medium, who was prominent in the Gisborne area, having worked for Transit 
New Zealand and other organisations reinterring human remains. Following an initial meeting with the matakite, Wyllie returned to the board to request resourcing to finance the repatriation project and, once this was approved, the matakite returned to Tairāwhiti Museum to identify the provenance of the kōiwi tangata (Wyllie 2011).

The kōiwi tangata were laid out on tables so the matakite could do "readings" of each in turn, identifying their provenance and where they needed to be reburied. Based upon this information, and personally satisfied with its accuracy, Wyllie spent a week and a half in 2007 travelling to the various locations, reburying the kōiwi tangata (Wyllie 2011). He is the only person who knows where they are reburied (Wyllie 2011). During 2011, Wyllie found some more human remains in a separate part of the Museum's collections, which will now need to be reburied (Wyllie 2011). Once these reburials have been completed, Tairāwhiti Museum's repatriation project will be finished.

\section{Conclusion}

Kōiwi tangata were extensively collected and traded between the eighteenth and twentieth centuries. New Zealand museums played a pivotal role in this trade, which has resulted in large collections of kōiwi tangata being held in institutions both here and abroad. For this reason, repatriation is an issue that many New Zealand museums now face, as they have increasingly reflected on their relationships with Māori and accepted that neither display nor continued storage of kōiwi tangata is appropriate. The examples of Auckland Museum, Te Papa and Tairāwhiti Museum's attempts to repatriate their kōiwi tangata collections demonstrate that as Māori involvement in these museums has increased there have been changes in how kōiwi tangata are regarded. In every case, these repatriation projects were preceded by a fundamental shift in the way these museums engaged with Māori, which was adopted into their legislation. Additionally, these examples show that repatriation processes are complex, requiring a large amount of time, resources and energy, regardless of the size of the project. In the following chapter, I look specifically at the work of Karanga Aotearoa in more depth, discussing three repatriation cases they have undertaken. This will demonstrate further the intricacies of the repatriation process. 


\section{Chapter Two - Repatriation case studies}

As discussed in Chapter One, Te Papa has a government mandate to undertake repatriations of Māori and Moriori kōiwi tangata from foreign museums and institutions. The Karanga Aotearoa Repatriation Programme, based at Te Papa, is the only programme in the country that carries out both international and domestic repatriations. In this chapter, I discuss the work of Karanga Aotearoa in more depth. I provide an overview of the processes Karanga Aotearoa expects to follow for international and domestic repatriations and discuss three examples of Karanga Aotearoa's repatriation work in practice. These examples, which are the domestic return from Te Papa to the Rangitāne o Wairau iwi and international returns from the Natural History Museum in Rouen, France, and the British Museum in London, further demonstrate the complexities of the repatriation process.

\section{The Karanga Aotearoa Repatriation Programme overview}

Since 2003, Te Papa has been authorised as an agent of the Crown to coordinate the repatriation of Māori and Moriori kōiwi tangata from foreign museums and institutions back to New Zealand. This mandate came after consultation with iwi at a series of wānanga between 1999 and 2001, which gave support for Te Papa's repatriation efforts and gave an iwi mandate for that work to continue. The government mandate provides funding for a dedicated repatriation team, including a manager, coordinator and up to two researchers. Additionally, it provides funding for the physical repatriations, including costs associated with travel for Te Papa staff and transport for the kōiwi tangata. The name given to this repatriation programme, Karanga Aotearoa, was chosen by the late Te Ikanui Kapa.

"Karanga" means "beckoning call" and so conveys the importance of repatriation for both the ancestors being returned and their descendents (Karanga Aotearoa Repatriation Programme $2010,3)$. Each staff member of the programme has a specific role, to ensure the repatriation process runs smoothly. The coordinator organises the logistics of the physical repatriation and provides administrative support for the programme. The researchers identify which institutions internationally have kōiwi tangata and establish, where possible, the iwi the tūpuna (ancestors) belonged to through intensive provenance research. The manager oversees this work to ensure that the ancestors return to New Zealand. The Karanga Aotearoa team works together with other teams within Te Papa, such as the Iwi Relationships 
Department, and with organisations outside of Te Papa, such as Air New Zealand, the New Zealand Customs Service and the Ministry of Agriculture and Forestry, who together ensure that appropriate tikanga can be followed on the journey home and that biosecurity and customs processes will be performed in a respectful way (Hakaraia 2005). Additionally, the Repatriation Advisory Panel, comprising iwi representatives and kaumātua (elders), provide the team with independent expert advice on tikanga, mātauranga Māori and kōiwi tangata issues.

Hakaraia (2005) outlines the stages that international and domestic repatriations are expected to follow. In the case of international repatriations, the Karanga Aotearoa team will first develop a knowledge of what human remains are held overseas. This information either comes from research into the trade of kōiwi tangata or from asking museums or institutions directly about whether kōiwi tangata are in their collections. Once it has been established that a museum or institution has human remains that might be from New Zealand, the team requests all records and provenance information the museum has relating to them, which allows them to ensure that the remains are Māori or Moriori and perhaps to identify to which iwi they belong. The Karanga Aotearoa team also provides the museum or institution with information about the programme, their mandate, and the significance of the remains to Māori and Moriori. When this information has been given, Te Papa makes a formal request and the negotiation for repatriation begins. A goal of the repatriation process is that it will lead to an ongoing relationship and research exchange with the repatriating institution. If provenance research has identified which iwi the remains originated from, then the Karanga Aotearoa team contacts the iwi as early as possible to notify them of the repatriation, allowing them to participate in the pōwhiri (welcome ceremony) when they return to New Zealand (Hakaraia 2005).

Once kōiwi tangata have returned to New Zealand, they are cared for in a wāhi tapu at Te Papa until the iwi to which they belong has been established. As well as internationally repatriated kōiwi tangata, there are kōiwi tangata in the wāhi tapu that have been transferred from the collection of the National Museum to Te Papa's care. In the case of domestic repatriations, the Karanga Aotearoa team first conducts research into where in the country kōiwi tangata are from. Contact is then made with the iwi to establish the basic arrangements for the repatriation ceremony, including when, to whom and to where the kōiwi tangata will 
be returned. The iwi are also given a report with all documentation and research related to the kōiwi tangata (Hakaraia 2005).

As repatriations must be "by mutual agreement only" according to the government mandate, the actual application of these processes is less straightforward. This is because Karanga Aotearoa negotiates repatriations while contending with deadlines, budget constraints, international law and the repatriation processes of other museums, which can be affected by personal opinions (Cabinet Policy Committee 2003, 2; Hakaraia 2005).

\section{Rangitāne o Wairau}

Wairau Bar, an isolated gravel bar where the Wairau River meets Cloudy Bay in Marlborough in the South Island, is one of the earliest known human settlements in New Zealand. Le Pla (2009) explains the history and significance of the site. As an archaeological site, it is immensely important for the study of the early settlement of New Zealand. Occupation began there between the end of the $13^{\text {th }}$ century and the beginning of the $14^{\text {th }}$ century. The burials and artefacts found there showed that New Zealand was settled from the Pacific and that moa-hunting was an activity adopted by some Māori when they arrived in New Zealand. Some of the tūpuna whose burials were uncovered at Wairau Bar, or possibly their grandparents, are thought to have been born in the Pacific before coming to New Zealand. Excavations began at the site in 1939 and continued until the 1960s. Local iwi protests against the removal of taonga and kōiwi tangata began shortly after the excavations commenced and have continued for three generations (La Pla 2009). All kōiwi tangata from Wairau Bar, which had been held by both Te Papa and Canterbury Museum between 1939 and 2009, have now been repatriated to their iwi Rangitāne o Wairau.

Excavations began at Wairau Bar in 1939 upon the discovery of human remains at the site by thirteen-year-old Jim Eyles, who lived with his family farming on Wairau Bar. Moa bones had been found on the farm, encouraging Eyles to fossick around for more (Wairau Bar Blog website; see also Le Pla 2009). Using an old potato fork, Eyles uncovered a woman's remains in a grave with a large moa egg and a necklace made with sperm whale teeth and moa-bone reels (Wairau Bar Blog website). The find was featured in the Marlborough Express, following which the moa egg and necklace were displayed in Eyles' uncle's fish and chip shop and returned each night in a biscuit tin to a bank vault (Wairau Bar Blog website). 
The moa egg, necklace, and the woman's skull were sold to the Dominion Museum in 1939 for $£ 130$ (Wairau Bar Blog website).

In 1942, Eyles was building a bomb shelter near where he found the first grave, when he found another grave with an even larger number of grave goods (Wairau Bar Blog website). This find prompted Roger Duff, the ethnologist at Canterbury Museum, to visit the site and begin his own excavations. Canterbury Museum continued to excavate the site until the 1960s, eventually uncovering forty-four burials, some with the remains of multiple individuals. Canterbury Museum's Wairau Bar collection includes 147 taonga found in burials, two thousand other artefacts found on the site, and approximately four thousand animal bones (Wairau Bar Blog website). In 2009, Canterbury Museum repatriated all fiftyfour kōiwi tangata it held back to Wairau Bar - a repatriation that Te Papa also participated in. However, this was not the first repatriation of a Wairau Bar tupuna (ancestor), as there had been a previous repatriation from Karanga Aotearoa to Rangitāne o Wairau in 2005.

In June 2005, Te Papa loaned a number of taonga to Millennium Art Gallery, Blenheim, for an exhibition of Marlborough Māori art and history. At the same time, Te Papa returned the remains of the woman Eyles had sold to the Dominion Museum in 1939 (Hubbard 2005). ${ }^{12}$ The tupuna, known by iwi as "Number One Woman" or the "Old Lady", was reburied at Māori Island Cemetery in Grovetown (Hubbard 2005; Smith 2009). This repatriation meant that Te Papa had a pre-existing relationship with Rangitāne o Wairau when the repatriation from Canterbury Museum was organised.

After the return of the "Number One Woman" for reburial, Te Papa continued to hold the remains of one other tupuna from Wairau Bar. The remains of this tupuna comprised a skull with eight "chipped and worn" teeth (Karanga Aotearoa Repatriation Programme 2009a, 4). Karanga Aotearoa research has shown that the kōiwi was likely to have been collected by Eyles' friend Peter O'Sullivan during excavations that occurred between 26 December 1951 and 18 January 1952. The skull went to the Ministry of Māori Development Te Puni Kōkiri, who then presented it to the Dominion Museum (Karanga Aotearoa Repatriation Programme 2009a, 4-5). Through descriptions of the burials, the Karanga Aotearoa team was able to establish that the skull in their collection could only have come from one of four particular

\footnotetext{
${ }^{12}$ This article incorrectly identifies the tupuna as male.
} 
burials at Wairau Bar (Karanga Aotearoa Repatriation Programme 2009a, 6). It is unclear why this tupuna was not returned at the same time as "Number One Woman" (Herewini 2011). The repatriation from Canterbury Museum to Rangitāne o Wairau that was to occur in April 2009 provided the perfect opportunity to negotiate the return of this tupuna.

In 2008, Rangitāne o Wairau established a deal with Canterbury Museum, the Ministry of Māori Development Te Puni Kōkiri, the University of Otago, the Historic Places Trust, the Department of Conservation and the current Wairau Bar landowner which allowed for the return of the tūpuna (Le Pla 2009; McCarthy 2011, 220). Canterbury Museum agreed to return the kōiwi tangata, providing that they could first perform DNA testing and other research at the School of Anthropology at Otago University, and that they would be buried in an acceptable place sealed from the elements (Smith 2009). In January 2009, as part of their Treaty of Waitangi settlement, the Crown gave Rangitāne o Wairau an area of Wairau Bar specifically for the reinterment of kōiwi tangata, allowing the tūpuna to be reburied as close as possible to their original resting places (Karanga Aotearoa Repatriation Programme 2009a, $8)$.

Because of the repatriation of "Number One Woman", Rangitāne o Wairau was aware of the second tupuna at Te Papa (Aranui 2011). Rangitāne o Wairau contacted Karanga Aotearoa early in 2009 to discuss the possibility of returning this tupuna as part of the Canterbury Museum repatriation. With this short deadline of only four months until the repatriation, Te Herekiekie Herewini, the Manager of Karanga Aotearoa, responded with information about the kōiwi tangata in Te Papa's collection (as is typically done in negotiating domestic repatriations) (Herewini 2009). Additionally, he stated that Karanga Aotearoa would happily make arrangements to have the kōiwi returned at the same time as the Canterbury Museum repatriation (Herewini 2009). Three iwi - Rangitāne o Wairau, Ngāti Toa Rangatira and Ngāti Rārua - have interests in Wairau Bar. Rangitāne o Wairau were the only inhabitants until Ngāti Toa Rangatira and Ngāti Rārua migrated to the area in the 1820s and 1830s, meaning that the tūpuna from Wairau Bar would be affiliated with Rangitāne o Wairau based on their age (Karanga Aotearoa Repatriation Programme 2009a, 8). Because of these overlapping interests in the site, Karanga Aotearoa negotiated repatriation with Rangitāne o Wairau, but notified Ngāti Toa Rangatira and Ngāti Rārua of the repatriation (Herewini 2011). 
The repatriation ceremony was large and continued over several days. On 14 April 2009, the tūpuna were collected from Canterbury Museum and returned to Wairau Bar on 16 April, via overnight stops at Takahanga Marae in Kaikoura and Omaka Marae in Blenheim (Wairau Bar Blog website). Prior to this ceremony, Richard Bradley, the Chief Executive of Rangitāne o Wairau and a leader of the repatriation efforts, collected the tupuna from Te Papa in a small ceremony (Aranui 2011). Kukupa Tirikatene, Te Papa's Ngāi Tahu kaumātua at the time of the second Wairau Bar repatriation, was Karanga Aotearoa's only representative at the repatriation ceremony.

The repatriation ceremony was emotive and McCarthy $(2011,220)$ notes that Tirikatene was initially taken aback by the anger expressed by the young men who had come to collect the kōiwi tangata from Canterbury Museum. Additionally, Tirikatene was aware of tension between Canterbury Museum and Rangitāne o Wairau (McCarthy 2011, 220). The negotiations between Canterbury Museum and Rangitāne o Wairau were at times challenging and the ultimate agreement to repatriate the kōiwi tangata and allow for research to occur was a compromise (see McCarthy 2011, 219-221; Smith 2009). McCarthy (2011, 220) notes that the director of Canterbury Museum, Anthony Wright, has "very strong concerns" about repatriation in general and initially gave a "cool response" to Rangitāne o Wairau. Finally, however, Wright felt that the end compromise of repatriation with research was a fantastic result (McCarthy 2011, 220). As well as archaeological work, so far this research has resulted in facial reconstruction of three of the tūpuna. Bradley commented that, "To be able to look at one of my own ancestors from the $12^{\text {th }}$ century - [it's] pretty cool" (One News 4 April 2010).

In contrast with the, at times, fraught negotiations between Canterbury Museum and Rangitāne o Wairau for the return of the tūpuna, the negotiations between Rangitāne o Wairau and Karanga Aotearoa were amicable and fast-moving. In this case, the negotiations were relatively easy because of the pre-existing relationship between the two. The strangest elements of this case are the speed with which the repatriation was organised and that it was combined with a planned repatriation from another museum. These challenges did not prevent a successful outcome because of that pre-existing relationship and because Karanga Aotearoa's policy is for returns to iwi to be unconditional, meaning, for example, that provisions for research did not need to be negotiated. Furthermore, Karanga Aotearoa had the resources to make working towards this short deadline a priority. 
Unlike most domestic repatriations, the repatriation from Canterbury Museum to Wairau Bar gained a lot of media attention because of the number of kōiwi tangata repatriated and because it was the first repatriation from Canterbury Museum. According to Bradley, media attention was sought even prior to the repatriation as a way to progress the negotiations, which in his words "probably wouldn't have happened" otherwise (Le Pla 2009). Generally speaking, however, domestic repatriations from Te Papa are done quietly in contrast to international repatriations, which attract a higher amount of media attention and debate.

\section{Natural History Museum, Rouen}

The repatriation of a Toi moko from the Natural History Museum in Rouen, France, courted controversy in 2007, when it was stopped by the French Minister for Culture and Heritage, Christine Albanel, because the return was illegal under French law. Following this decision, specific legislation was created to allow the return of this Toi moko and all others in French museums. This Toi moko was repatriated to Te Papa in 2010, three years after repatriation was first suggested. As well as being the first repatriation of a Toi moko from France, the law change that preceded it meant this repatriation was high-profile.

The Natural History Museum in Rouen opened in 1828 in a former convent built circa 1640 (Musées en Haute-Normandie website). The Toi moko had been donated to the Museum in July 1875 by a Parisian named Drouet and was displayed with the prehistoric collection until the museum closed for refurbishment in 1996 (Mail Online 9 May 2011; BBC News 9 May 2011). During its refurbishment, in 2003 the Museum was given the designation of "Museum of France”, which meant that it was subject to laws about deaccessioning its collections (Bel, Berger and Paterson 2008, 225). When the Museum reopened in 2007 it had a new collections philosophy and no longer saw retaining the Toi moko as appropriate. The Mayor of Rouen, Pierre Albertini, explained that, "By returning the head, we seek to make an ethical gesture, rooted in respect for the culture of peoples and the innate dignity of every human being" (Field 2007). Upon deciding that the Toi moko should be repatriated, the Museum's director, Sebastien Minchin, discussed repatriation with Rouen officials and the New Zealand embassy before contacting Karanga Aotearoa to arrange the specific details of the transfer.

The repatriation ceremony for the Toi moko was scheduled for October 2007. Owing to budget constraints, Karanga Aotearoa staff were unable to be present at the ceremony for a 
physical handover, so they planned to retrieve the Toi moko in November at the same time as pre-arranged repatriations from England. Although Karanga Aotearoa were not present at this symbolic ceremony, the New Zealand delegation included chief of Ngāti Tūwharetoa, Tumu Te Heuheu, and Dame Silvia Cartwright, then the Chair of the New Zealand National Commission for UNESCO and New Zealand's Governor-General between 2001 and 2006.

Prior to this repatriation, France had once previously repatriated human remains. After years of campaigning, and with encouragement from Nelson Mandela, in 2002 the French Government had agreed to repatriate the remains of a South African woman, the so-called "Hottentot Venus", Saartjie Baartman. Baartman had been exhibited as a freak during her lifetime in both London and Paris. When she died in Paris in 1815, her body was publically dissected, then preserved and displayed in the Musée de l'Homme until 1974 (Holmes 2007). ${ }^{13}$ The decision to repatriate her body was based in part on Article 16-1 of the French Civil Code, which states that, "The human body, its elements, and its products cannot be the object of proprietary rights" (Amiel 2008, 372). At the time of her repatriation, a scientific body was established to consider claims to deaccession items in French museum collections. It was decided that the repatriation of Baartman's body should not go through the approval of this scientific body, as she had been subjected to a number of humiliations at the hands of science both during and after her lifetime (Amiel 2008, 372-373).

The idea that the human body could not be owned and the decision to repatriate Baartman's body were thought by some to set a precedent for the return of other human remains in French museums. This was precisely the reason that the Natural History Museum believed the repatriation of the Toi moko would be possible, with Rouen's Deputy Mayor and Senator, Catherine Morin-Desailly, citing it specifically as a precedent (Sciolino 2007). Furthermore, the Mayor of Rouen, Pierre Albertini, stated on the eve of the planned October 2007 repatriation that, "Under French law human body parts do not come under the laws of national heritage, nor can they be owned by a public entity" (Field 2007). Prior to discussing the possibility of repatriation with Te Papa, the officials in Rouen had sought approval from the Rouen city council, and notified the Ministers of Research and Higher Education, Culture, and Foreign Affairs about the decision to repatriate. However, the day before the repatriation

\footnotetext{
${ }^{13}$ For a thorough discussion of Saartijie Baartman's life and the repatriation of her body to South Africa see Holmes, Rachel, 2007. African Queen: the real life of the Hottentot Venus. New York: Random House
} 
was to occur, the French Minister for Culture and Heritage, Christine Albanel, questioned its legality.

The repatriation decision was referred to a tribunal, which agreed that the proper authority to repatriate the Toi moko had not been given. The tribunal asked the question, "Is the head a French public good that must be declassified before it can be returned, or is it a body part (and not a work of art) that can be immediately returned in order to be properly buried?" (Bel, Berger and Paterson 2008, 223). At the time, items in French museum collections were considered to be "public goods" that could not be deaccessioned without the approval of the National Scientific Commission on Collections, established at the time of Baartman's repatriation (Paterson 2010, 646; Auckland District Law Society website 2011; Bel, Berger and Paterson 2008). According to Article L451-3 of the Heritage Code, "The collections of the museums of France are inviolable" and according to Article L451-5, "Goods constituting collections of the museums of France... are in the public domain and are hence inalienable. Any decision to declassify such goods cannot be made without the assent of a scientific body..." (Bel, Berger and Paterson 2008, 224). These provisions could be seen to contradict Article 16-1 of the French Civil Code that, "The human body, its elements, and its products cannot be the object of proprietary rights" (Amiel 2008, 372), but the tribunal found that keeping human remains in museum collections does not go against this principle. Therefore, human remains still required approval from the National Scientific Commission on Collections to be deaccessioned (Bel, Berger and Paterson 2008, 225).

Because the repatriation decision made by Rouen was found to have a "procedural error", the decision was annulled (Bel, Berger and Paterson 2008, 226). On 8 January 2008, the city of Rouen announced that Morin-Desailly was preparing a special bill to allow the automatic repatriation of all Toi moko in French museums without the approval of the National Scientific Commission (Amiel 2008, 374). This bill was introduced in the French Senate on 20 February 2008 and passed by the Senate on 29 June 2009 (Paterson 2010, 647). The bill was passed into law on 4 May 2010 and came into force two weeks later (Paterson 2010, 647). The law states that, "As of the date of entry into force of the present legislation, the Māori heads kept by French National Museums (Musées de France) shall cease to be part of 
their collections in order to be returned to New Zealand" (Paterson 2010, 647). ${ }^{14}$ This law puts Toi moko outside the provision of inalienability that governs items in French museum collections. However, it does not apply to Toi moko in non-museum institutions, such as universities, as these Toi moko were never subject to the inalienability principle. Those institutions have always been free to repatriate Toi moko and other human remains without requiring approval. Additionally, the law does not specifically mention the repatriation of other kōiwi tangata, although it does create provisions for the handling of future repatriation requests for any human remains.

Most of the provisions of the Toi moko law concern the role of the National Scientific Commission on Collections (Paterson 2010, 647). There was a feeling that the Commission was failing, as it had never made a declassification ruling (Paterson 2010, 647). A new commission, comprising state and regional representatives, curators, art historians, philosophers, a senator, and a member of the National Assembly, has the sole responsibility of considering museum requests for declassification, meaning that no specific legislation will again be required before a repatriation can occur (Paterson 2010, 647).

With this change to French law, it was possible for the Natural History Museum to repatriate the Toi moko in May 2011. The Toi moko was repatriated at the same time as kōiwi tangata from four other European institutions, including two German museums, and universities in Sweden and Norway, with a pōwhiri at Te Papa when they returned to New Zealand. ${ }^{15}$ Following the handover ceremony in Rouen, Minchin, who was a strong supporter of the repatriation, commented that the case, "has given me grey hair. It's the culmination of debate, and, indeed, battle to achieve this result" (Tahana 2011). Te Kanawa Pitiroi, a kaumātua involved in the ceremony, pragmatically acknowledged that, "I've heard it's taken five or six years to get to this stage but the tupuna has been waiting for over 130 years so these last few years have meant nothing" (Tahana 2011).

The change to French law required that all Toi moko in the collections of "museums of France" be repatriated to New Zealand. Because of this, twenty Toi moko from nine French

\footnotetext{
${ }^{14}$ Paterson has translated the term "Musées de France" as "French National Museums". It should be noted that these museums include both National museums (such as the Louvre) and provincial museums (such as the Natural History Museum in Rouen).

${ }^{15}$ Lund University in Sweden repatriated kōiwi tangata collected by Meinertzhagen and sent to them via Haast, which was mentioned in Chapter One.
} 
museums and one university, which opted to take part, were handed back to Karanga Aotearoa for repatriation in a ceremony at Quai Branly Museum in January 2012 (New Zealand Ministry of Culture and Heritage website 2012). The ceremony was held on the day that the exhibition of Māori culture, Māori: leurs trésors ont une âme (Māori: their treasures have a soul) was closed after three months at the Museum. ${ }^{16}$ With this handover, the repatriation of all Toi moko in French museums was completed. ${ }^{17}$ Currently there is no indication that French museums hold kōiwi tangata and this will not be investigated until after provenance research for the Toi moko has been completed (Herewini 2011).

The length of time this repatriation case took to resolve and its twists and turns through complex laws show just how complicated repatriation processes can be. The legal issues that were faced were not anticipated by those involved in the original repatriation attempt but French repatriation supporters confronted these challenges with passion, ultimately achieving the repatriation of all Toi moko from French museum collections. This outcome was not foreseen when negotiations for the initial repatriation began and can therefore be seen as a massive achievement. Karanga Aotearoa staff praise the "thoughtful" way in which the French led the campaign to repatriate Toi moko and think that this process will have started to change European attitudes towards repatriation (Mamaku 2011; Aranui 2011). Although similarly lengthy, this forthcoming French-led process was a quite different experience to the negotiations with the British Museum, which show the difficulties involved in negotiating repatriation with institutions that have a strong presumption against its benefits.

\section{The British Museum, London}

In 2008, the British Museum repatriated nine kōiwi tangata to Te Papa, but declined the repatriation request of seven Toi moko. Following the British Museum's repatriation procedure, the request took several years to negotiate, as reports on the benefits of retaining the kōiwi tangata and Toi moko were commissioned. However, the decision the Trustees of the British Museum arrived at appears to challenge the principles of their policy and the findings of the independent reports.

\footnotetext{
${ }^{16}$ This exhibition was first shown at Te Papa where it was named E tū ake:Standing strong.

${ }^{17}$ One university with a Toi moko chose not to take part in the January 2012 repatriation. This Toi moko remains in France.
} 
The British Museum's Policy on Human Remains, approved in 2006, outlines the circumstances in which the Trustees of the British Museum can agree to the repatriation of human remains in the collection. The policy explains that there would be an assumption that the collection should remain intact, except in rare cases. The Trustees are unlikely to accept repatriation claims for hair, teeth, nails, or for "human remains that have been modified for a purpose other than mortuary disposal" (British Museum 2006b, 7). In this policy "mortuary disposal" refers to "any process (such as, for example, burial or cremation or any appropriate cultural equivalent of these processes) the purpose of which is the laying to rest of human remains in a context that is specific to a particular cultural [sic] or society" (British Museum 2006b, 4). The Trustees will only consider claims from: a community with the support of a national government or agency; representatives of a community if they have authority to submit a claim; or a national government or agency representing a community if it can be shown both that the community has cultural continuity with the remains and that the community wishes for them to be returned. To be successful, the Trustees have to be satisfied that: the remains were originally subjected to mortuary disposal or were intended for mortuary disposal; they are less than one hundred years old with direct and close genealogical links with the claimants or if they are more than one hundred years old the claimants have cultural continuity (religious beliefs or cultural practices in common) with them and the remains have cultural importance for the community, meaning either that the treatment of the remains has particular significance or the Museum's continued holding of the remains “perpetuates strong feelings among the claimants' community" (British Museum 2006b, 8). The Trustees assume that the balance of probabilities lies strongly with retaining human remains in the collection if they are more than three hundred years old and very strongly if they are over five hundred. The repatriation claim has to pass a "public benefit test" in which the Trustees consider whether the significance of the genealogical link with remains under one hundred years old is more important than the benefit to the world community of keeping the remains, or, when older than one hundred years, that the significance of the cultural continuity and cultural importance to the claimant community outweighs the benefit of retaining the remains for the world community.

Prior to Te Papa's repatriation request, the Trustees of the British Museum had received only one other request. In that case, the Trustees agreed to repatriate two ash bundles to Tasmania. Ash bundles were traditionally worn as amulets to protect against ill health, having been created in a time of need by collecting the ashes of a deceased person and 
wrapping them in animal skin (British Museum website, Request for repatriation of human remains to Tasmania; British Museum 2006a). These two ash bundles were the only two of their kind known to exist but research about them had been published (British Museum website; British Museum 2006a). In making their decision, the Trustees were satisfied that the collection and deposit of the ash bundles in the Museum interrupted a traditional process of mortuary disposal and that they were of no further value to the study of humanity. However, the decision the Trustees ultimately made when Karanga Aotearoa requested the repatriation of Toi moko and kōiwi tangata is not in keeping with this earlier decision.

Until 2008, the British Museum's collection included nine fragmentary pieces of bone, seven Toi moko and a further twenty-two objects incorporating human remains such as fishhooks and jewellery, all with provenance to New Zealand. Most of the seven Toi moko were acquired by the Museum in the nineteenth and early twentieth centuries, although three of the Toi moko could have entered the collection in the late eighteenth century (British Museum 2006c). Robley $(2003,198)$ mentions there were four Toi moko at the British Museum by 1896. The nine bone fragments were part of the Meinertzhagen collection, the British Museum's largest Māori collection with over six hundred items, presented to the Museum in 1895 (British Museum 2007). Meinertzhagen, mentioned in Chapter One for his kōiwi tangata donations to Haast at Canterbury Museum, lived in Waimārama in the Hawke's Bay between 1866 and 1881, during which time he keenly collected Māori and Moriori artefacts from across New Zealand and the Chatham Islands. Two of the kōiwi he collected that went to the British Museum are provenanced to "New Zealand" whereas the other seven are provenanced to the "North Island, New Zealand" (Aranui 2009). Based on what is known of Meinertzhagen's collecting activities, it is likely that the nine kōiwi tangata are from Waimārama but this cannot be stated with certainty (Aranui 2009). Other kōiwi tangata collected by him were from the Waimārama sandhills and were sent to Haast at Canterbury Museum (Aranui 2009). Four of the nine kōiwi tangata, including two crania, have evidence they have been burnt, possibly during cremation (British Museum 2006c; Besterman 2007). The other five kōiwi tangata have been cut at one or both ends and are described as “implements" in some British Museum records (British Museum 2006c).

Karanga Aotearoa's mandate specifies that they can only request repatriation of unmodified kōiwi tangata, including Toi moko. Because of this, they could not request modified human remains such as the twenty-two objects made from Māori or Moriori human remains in the 
British Museum collection. Although Karanga Aotearoa cannot request repatriation of such modified human remains, they can accept them if an institution offers them for repatriation. For example, the Manchester Museum wished to repatriate a fish hook made from human bone at the same time as repatriating kōiwi tangata, so this was accepted (Aranui 2011). The status of the nine kōiwi tangata was confusing because some were described as "implements", meaning that they potentially could fall into the category of "modified" human remains. Te Papa requested clarification of the status of these five kōiwi in April 2006, but as this was not given, they were included in the repatriation request (Te Puni 2006; Bennington 2007). Besterman (2007, 7-8) found that, with the possible exception of one bone fragment that showed wear, the term "implement" was inappropriate, describing them instead as "reduced in length after death for an unknown purpose".

Eventually, the British Museum decided to repatriate the nine kōiwi tangata, but retain the seven Toi moko. This decision was made because the Trustees felt that the nine kōiwi tangata had likely been disturbed after a process of mortuary disposal and their importance to Māori outweighed the public benefit of retaining them (British Museum website, Request for repatriation of human remains to New Zealand). On the other hand, in the case of the Toi moko they felt it was unclear that a mortuary disposal process had been disturbed and they were unsure that the Toi moko are of more importance to Māori than they are as a resource to provide information about human history (British Museum website, Request for repatriation of human remains to New Zealand). In reaching this decision, the Trustees sought advice from independent advisors and sent their Head of the Oceanic Collections, Lissant Bolton, to New Zealand to ascertain contemporary Māori views about repatriation.

In her report, Bolton found that most Māori felt that kōiwi tangata, including Toi moko, should be returned to New Zealand. However, she found that one person felt that something should be given in exchange for Toi moko and others felt that they would prefer the relevant iwi to be identified before return (Bolton 2007, 112). Bolton made this trip to New Zealand because the British Museum's Policy on Human Remains requires, as mentioned, that when claims for repatriation come from a government, the community in question has cultural continuity with the remains and the remains have cultural importance for them (Bolton 2007, 112; British Museum 2006b, 8). As Karanga Aotearoa has a clear iwi mandate for its work, Bolton's visit could be interpreted as unnecessarily complicating the repatriation process for the British Museum. 
The first independent report commissioned, prepared by Phillip Endicott, was intended to assess the value to science of the seven Toi moko and nine kōiwi tangata. However, the report has limited discussion of the actual value of these particular remains to science, concluding only that they would be suitable for unspecified isotopic analysis of diet and molecular biology (Endicott 2007, 16). Robert Foley, Professor of Human Evolution at the University of Cambridge, was asked by Andrew Burnett, the Deputy Director of the British Museum, to comment on Endicott's report. Of the significance of the remains to science, Foley $(2007,2-3)$ states, "As the report stands it is difficult for me to evaluate this except in the most general manner," but he concludes that based on his reading, the "report suggests that these remains do have a public benefit... in terms of being a record of the varied ways of life in the past... and can help advance knowledge, particularly in terms of genetics and other markers of population history...." This conclusion is contrary to the advice of Tristram Besterman, the author of the second commissioned report. With regards to the public benefit test and the value of the remains to social and biological anthropology research, Besterman $(2007,21)$ explains that:

The benefits of repatriation in my view overwhelmingly outweigh those of retention. Te Papa recognises the right of holding institutions to carry out research on kōiwi tangata prior to return, so there is an opportunity for the BM to work with Te Papa to answer the kind of research questions outlined above.

Thus research goals would be better served through repatriation rather than retention of the Toi moko and the kōiwi tangata.

Besterman's report was resoundingly in favour of repatriation for all Toi moko and kōiwi tangata in the British Museum's collection, showing that according to the British Museum's Policy on Human Remains, the Toi moko and kōiwi tangata meet every test of public benefit, cultural continuity, cultural importance and mortuary disposal. However, Besterman (2007, 20) points out that with regards to mortuary disposal "there is dissonance between the BM's definition, and the purpose and treatment of Toi moko in Māori society" as they are not "laid to rest" in a strict Western sense. Both Tapsell $(2005,155)$ and Aranui $(2011)$ note that Toi moko were ultimately laid to rest. Aranui (2011) states that, "I know just from reading that Toi moko have been found in caves so eventually they are put to rest but we've just got to provide that evidence." Even once this evidence is provided, because Toi moko had a ceremonial role in rituals such as tangihanga, this dissonance would not be resolved. 
Besterman $(2007,20)$ suggests that because "it is unlikely that the Policy was intended to exclude such human remains, it is recommended that the BM should review whether the drafting as it stands is appropriate to remains of this kind".

Neither Besterman's advice to alter the Museum's policy nor to repatriate the Toi moko were followed by the Trustees. ${ }^{18}$ Comments made by British Museum staff as well as their decision not to repatriate the Toi moko show confusion about the significance of Toi moko. Karanga Aotearoa staff member Kay Harrison (2007) records what happened in a meeting between herself, Burnett and Bolton. Bolton and Burnett suggested that Toi moko could be regarded as having been modified for a purpose other than mortuary disposal, seemingly referring to the post-mortem tattooing of slaves that sometimes occurred (Harrison 2007). Harrison responded that Karanga Aotearoa is concerned with the interests of the person and their descendent community rather than those who sold him (Harrison 2007). According to Harrison, Bolton and Burnett seemed to be suggesting that, "Māori did this therefore perhaps Māori could not expect to ask for them back" (Harrison 2007). Once the decision had been made, Burnett $(2008,17)$ commented that whereas:

The Tasmanian cremation ash bundles and Māori bones were clearly intended for mortuary disposal. The status of the preserved heads is unclear: some were preserved as revered ancestors, but others were trophies of defeated enemies and others seem to have been produced for sale to Europeans. So it's not clear they were all destined for mortuary disposal.

To this Besterman $(2008,17)$ responded that neither the ash bundles nor the kōiwi tangata were clearly intended for mortuary disposal and "Burnett's explanation merits scrutiny, both for the way in which the Te Papa claim was handled and the light it sheds on the values and assumptions of the British Museum more generally."

The British Museum's position implies that it is acceptable to retain Toi moko if they were "intended" for trade rather than mortuary disposal even though in those cases people were killed specifically so their heads could be sold. Besterman (2007, 18-19) argues that:

\footnotetext{
${ }^{18}$ The Policy was reviewed as scheduled in 2011 but the term "mortuary disposal" is expected to be retained when it is made public (Natasha Smith, curator Oceania Pacific collections, British Museum, pers comm. $15 / 11 / 2011)$.
} 
No one would be taken seriously today who argued that the sale of slaves from West Africa more than two centuries ago was done with their consent merely because their Black brothers colluded willingly in the trade by procuring the human merchandise. By analogy, the fact that one Māori tribe traded willingly the Toi moko of their vanquished (or enslaved) brother should not obscure the underlying dispossession and lack of consent of the source iwi.

Besterman's analogy is powerful because this seems to be exactly the position of the British Museum. Bolton $(2007,111)$ found that contemporary Māori are uncomfortable distinguishing between kin, foe and trade Toi moko as these distinctions do not affect their value as ancestors.

Amongst Te Papa staff there is scepticism about the reasons the British Museum gave for their repatriation decision. This scepticism is demonstrated by Aranui (2011), who said:

In terms of these particular kōiwi that were repatriated, personally, I think they repatriated them because they had no use for them because, rather than being skulls or skeletons, they were just pieces of bone that appeared to have been cut in some way... I have a feeling that they didn't want to repatriate Toi moko also because it might set a precedent for other human remains having to go - for instance, the Egyptian mummies, because they would be seen as very similar. There are underlying reasons that they probably haven't said.

This suggests possible unspoken reasons the British Museum did not repatriate the Toi moko are that it would put other collections in danger of repatriation and because they could be valuable for research, which the British Museum thought could not be achieved through repatriation, despite advice saying research could occur. Additionally, Herewini (2011) explains the implications of the British Museum's position when viewed according to a Māori perspective:

The British Museum gave us back the kōiwi tangata, but said that because Toi moko, in their view, were never meant for mortuary disposal that's the reason they aren't repatriating those at the moment, but my argument back to them would be that if they want to use it in that sort of argument, in the cultural context, then they are saying that they are holding on to enemies' heads and so they are actually saying to us that they are the enemy, because they are holding on to our heads.

Similarly, Tapsell $(2005,156-157)$ notes that the exhibition of Toi moko mirrors the customary practice of displaying enemies' heads to denigrate them where "all and sundry could gaze". Even if they are removed from display, retaining them in the collection mimics their treatment by enemies, as Herewini (2011) claims. 
Although the British Museum decided not to repatriate the Toi moko in 2008, Karanga Aotearoa staff are committed to continuing to work with the British Museum to secure their return. Aranui (2011) explains that:

They declined repatriation of the Toi moko, but that doesn't mean we're going to stop trying now that we know what we need to do to put a better case forward to them and hope that they change their mind.

The Karanga Aotearoa team will simply prepare a stronger claim, with more evidence and explanation of Māori funerary practice and the mortuary disposal of Toi moko. However, preparing this information might take several years (Aranui 2011).

Although the British Museum has a clear policy on human remains and how to process claims for their repatriation, in practice their process is convoluted and tipped heavily in favour of retention of the remains. The negotiations for the return of the nine kōiwi tangata took four years, but it will take at least a few more years to secure the return of the Toi moko, showing how drawn-out the repatriation process can be. As Besterman $(2008,17)$ claims, this case reveals the values of the British Museum towards community engagement. Because repatriation cuts to the heart of what museums ought to be, these values are particularly resistant to change.

\section{Conclusion}

The three cases presented in this chapter demonstrate that even in the most amicable repatriation negotiations, problems can arise. Throughout the process, Karanga Aotearoa, and the groups that they negotiate with, face challenges such as deadlines, budget constraints, and obscure laws and policies that complicate negotiations. These difficulties need to be worked through to make repatriation happen and, ideally, establish a mutually rewarding partnership. Perhaps the hardest cases to negotiate are those in which one party objects to the idea of repatriation. As the case with the British Museum shows, if a museum or institution is opposed to repatriation in principle, and there is no legal imperative to repatriate human remains, as there eventually was in France, negotiations are likely to be very long and stacked in favour of retention. In the next chapter, I analyse some of the difficulties that are frequently encountered in the repatriation process and what makes repatriation negotiations successful, as well as the implications of this for museum practice. 


\section{Chapter Three - Problems, solutions, and implications}

As the case studies in Chapter 2 clearly demonstrate, repatriation is not straightforward. Rather, there are a number of difficulties that can arise during the repatriation process, ranging from logistical or budget constraints to ideological differences. Ultimately, if these difficulties are overcome and repatriation occurs, a rewarding partnership can emerge between those involved in the repatriation. However, the level of time, energy and commitment required for a successful repatriation should not be underestimated. In this chapter, I discuss some of the major challenges that complicate the repatriation process and what it ultimately takes to overcome these difficulties to make repatriation successful.

\section{Common challenges}

Bienkowski (forthcoming) argues that most repatriation processes are adversarial and longwinded, and favour the holding institution over the claimant. This lengthy, adversarial approach is demonstrated clearly in the repatriation negotiations between Karanga Aotearoa and the British Museum. Beginning from an assumption against repatriation enshrined in their Human Remains Policy (2006b, 3), the British Museum considered Te Papa's claim for four years as it progressed through a number of "tests", evaluating the legitimacy of Karanga Aotearoa as claimants and the possible benefits of retaining the human remains against their perceived value to Māori people. Although a decision was made in 2008, since the British Museum chose to retain seven Toi moko, negotiations for their return will continue. The British Museum's approach to repatriation typifies the adversarial process that Bienkowski describes, but even the least adversarial processes are not without their issues.

Even in cases where all parties would like the repatriation to occur, there can be problems with making it happen. For instance, Karanga Aotearoa and the Natural History Museum in Rouen agreed to the repatriation of the Toi moko in good faith, but neither had anticipated the legal issues that would prevent that return for three and a half years. Additionally, although Auckland Museum has been proactive in its approach to repatriation, they have returned relatively few of the kōiwi tangata in their building, despite expectations that up to $80 \%$ would be returned by the end of 2008 (Vodanovich 2011; Tapsell 2011). According to Vodanovich (2011): 
There was definitely an underestimation of what it takes to do this, so it's not just a transaction 'box them up, off they go, done, next' kind of thing and that each transaction requires quite a lot of time and energy and relationship-building to get to the point where people might feel comfortable taking these [human remains] back and I just think we were a bit optimistic about what could be achieved.

This indicates that willingness to repatriate does not remove certain challenges from the process, such as finding the time and resources with which to carry out repatriations or getting other people onside. The time that repatriation takes should not be underestimated, as both adversarial and non-adversarial approaches require a vast amount of time to work through issues that arise and to build relationships. For this reason, as Pickering $(2010,170)$ suggests, repatriation processes cannot be forced to fit around a set time frame, such as a financial year. ${ }^{19}$ Vodanovich (2011) notes that the timing of repatriations is set by iwi, rather than the museum and that this can be a difficult concept for those who are used to controlling things themselves. She explains that:

I know that Rangiiria had to tip-toe quite carefully with communities and certainly let them set the pace obviously about whether they wanted things returned or not. I think that's hard for some people who are more tick-the-box kind of people back here at the museum to understand - 'by July why wasn't 30\% returned or by August why wasn't 50?' you know - and that's just simply not the way it works. It's not one where we can dictate the pace at which other people want these things to happen and I think that's been a bit of a learning curve for people.

Because repatriation requires negotiation with other people and institutions, the timing of the process cannot be dictated by one party. Just as at Auckland Museum, issues with timing were faced by Tairāwhiti Museum and continue for Karanga Aotearoa. Despite its small scale, Tairāwhiti Museum's repatriation project took two years to complete and Karanga Aotearoa's experiences with the Natural History Museum in Rouen and the British Museum show just how protracted the process can be.

Finding the time and means to resource repatriations is a major challenge. Tairāwhiti Museum's use of a matakite shows that smaller museums can find pragmatic, culturally appropriate solutions to the issue of repatriation without trying to emulate the way in which Karanga Aotearoa operates. However, convincing Tairāwhiti Museum's Trustees to resource

\footnotetext{
${ }^{19}$ Under the terms of its mandate, the Karanga Aotearoa Repatriation Programme has a commitment to undertake a certain number of repatriations in each financial year. However, the number of kōiwi tangata left to repatriate far exceeds targets so in practice there is no pressure to rush the repatriation process.
} 
the repatriation project was difficult for Wyllie, although after some debate the Trustees agreed to fund the work (Wyllie 2011). In contrast, Karanga Aotearoa's funding is ensured through their government mandate and allows for four dedicated staff, and the costs of physical repatriations. Although Karanga Aotearoa is well resourced, budget constraints do limit what can be achieved in any given year. Each year, it is possible for a couple of Te Papa and Karanga Aotearoa staff to travel once to either Europe or the United States, or instead up to twice to Australia (Herewini 2011). Because of this, kōiwi tangata are retrieved from multiple institutions on each visit overseas. For instance, when the Toi moko was repatriated from the Natural History Museum in Rouen in 2011, five more institutions in Germany, Norway and Sweden repatriated kōiwi tangata at the same time. It would have been possible to complete repatriations from a further three European institutions on this visit, but budget constraints meant it was kept to five, which accords with Karanga Aotearoa's mandate to undertake at least five international repatriations each year (Herewini 2011). As Karanga Aotearoa returned to France in January 2012 to collect a further twenty Toi moko from ten institutions, there will be delays to repatriations from other countries, including the three institutions mentioned above, since the budget will not allow for further travel this financial year (Herewini 2011).

Since repatriation requires negotiation between people who might have differing viewpoints, ideological differences can have a serious impact on the speed and success of repatriation projects. These ideological differences include sensitivities about discussing human remains, definitions of modified and unmodified human remains and the belief that repatriation is generally undesirable. Finding people who will comfortably discuss the repatriation of human remains can be a challenge when first looking for people to be involved. It took one and a half weeks for Wyllie to personally rebury Tairāwhiti Museum's kōiwi tangata, but the previous two years had been spent waiting for people to help (Wyllie 2011; see also McCarthy 2011, 172). Wyllie contacted people in the community for their help, as some of the kōiwi tangata were from neighbouring tribes, but found that people were unwilling to discuss the issue. He explains that:

I got a few dial tones from people, so there's a perception, especially within the Māori community, a lot of people are very frightened of human remains and for some reason or another, they didn't want to have a bar of it. 
Similarly, at Auckland Museum some staff members who had jobs that in some way overlapped with the repatriation project did not want to become involved (Vodanovich 2011). In this case, the viewpoints of those staff were respected and they were not required to take part. Because human remains and repatriation are sensitive subjects for many people it can be difficult to get people to speak openly about it and their viewpoints must be accepted. For this reason, Wyllie has suggested that those responsible for Māori collections should identify people in their community who can deal with sensitive issues such as the reburial of human remains (McCarthy 2011, 172).

The scepticism around the British Museum's stated reasons for their repatriation decisions shows that even if people are willing to discuss repatriation they might not openly reveal all of their beliefs and assumptions. As discussed in Chapter Two, the outcome of Karanga Aotearoa's repatriation claim to the British Museum was contrary to some of the principles of their own policy, suggesting, as Besterman $(2008,17)$ notes, that, "The policy throws dust in our eyes." With regards to both this decision and their earlier decision to repatriate the Tasmanian ash bundles, Besterman $(2008,17)$ argues that, "The British Museum repatriates human remains against its policy and retains tattooed heads to which its criteria are not designed to apply." Because of this, there is doubt among Karanga Aotearoa staff that the real reasons that the Toi moko were retained and the kōiwi tangata were not have been revealed. Harrison recalled that at her first meeting with Burnett and Bolton, Burnett opened the meeting with a flippant comment akin to "I've always believed that if you are going to disagree with someone, you should at least meet them/know them" (Harrison 2007). This suggests that the fate of the claim might already have been sealed and that negotiations were not entered into with complete openness. Vodanovich (2011) notes that, "You can put whatever policies you like in place, but the beliefs about the process will actually influence how things go to a certain extent." These beliefs can affect the success of repatriation negotiations.

Unclear concepts and the beliefs of those involved in repatriation can shape the outcome of negotiations, as seen in the different decisions regarding the repatriation of the nine kōiwi tangata and seven Toi moko from the British Museum. The kōiwi tangata were repatriated because they were considered to have been intended for "mortuary disposal". Evidence of deliberate breakage of the kōiwi however suggests that there had been an attempt to make them into artefacts and, therefore, they could have instead been "modified for a purpose other 
than mortuary disposal". If it were judged that they were modified and that this was not part of a mortuary disposal, then their repatriation would have been outside the terms of the British Museum's policy. ${ }^{20}$ Both the concepts of mortuary disposal and modified versus unmodified human remains are open to interpretation. Museums with repatriation policies frequently mention that only "unmodified" human remains will be considered for repatriation. Whereas human remains policies in New Zealand museums, such as those at Te Papa and Auckland Museum, clearly define what is meant by the term "unmodified" and explicitly state that Toi moko fall into this category, international policies are unlikely to mention the status of Toi moko. This can complicate negotiations for their repatriation, as the historical European view of them as artefacts persists. For instance, as discussed in Chapter Two, in France prior to their law change, debate focused on whether Toi moko are artefacts or human remains (see Amiel 2008). The British Museum's decision to repatriate kōiwi tangata but not Toi moko shows that opposition to repatriation is a major difficulty in the repatriation process if that opposition is supported, either directly or indirectly, by policies that are subject to interpretation.

Cases in which the parties negotiating repatriation disagree on fundamental values can only be resolved through further discussion and education. Vodanovich (2011) explains issues about repatriation between Auckland Museum and other institutions which might not have previous experience with repatriation have been resolved by "meeting and talking and discussing and explaining". With regards to the British Museum, Karanga Aotearoa will continue to negotiate for the return of the Toi moko. According to Aranui (2011) they will again follow the procedures the British Museum has set, but will make a stronger claim in the future. This willingness to meet the British Museum on their terms and respect the procedures they have put in place, even when they have resulted in less than ideal outcomes in the past, shows a spirit of engagement with the values of others involved in the process. This understanding and easy-going approach is shared by Herewini, who recognises that people might need time to resolve their issues (legal or personal) with repatriation and that success will not be achieved through animosity. Herewini (2011) explains that, "Where we do have museums that don't agree to repatriation or they are considering it, to me it's not a big issue because we've got other things we can do." This flexibility to allow people the time they need keeps negotiations respectful. This respectful attitude was shown when the

\footnotetext{
${ }^{20}$ Besterman $(2007,19)$ concludes that although all kōiwi tangata have been modified, they have not yet become usable artefacts. This means they should still be considered for repatriation.
} 
repatriation of the Toi moko from Rouen was initially prevented. Rather than force the issue, Karanga Aotearoa allowed the French to reconcile their views and their laws for themselves. This will further dialogue and understanding for future engagement, especially with those museums who might not have participated in repatriation if they had a choice. For instance, Quai Branly Museum in Paris hosted the January 2012 Toi moko handover ceremony, but had previously been opposed to repatriation. Discussing the thwarted repatriation of the Toi moko from Rouen, Stéphane Martin, director of Quai Branly Museum, said in 2007 that, "Sending back these artifacts to New Zealand, and destroying them by burying them is a way of erasing a full page of history" (Sciolino 2007). By hosting the repatriation ceremony and the exhibition of Māori culture, Māori: leurs trésors ont une âme (Māori: their treasures have a soul), it appears that Quai Branly, for one, has now embraced the opportunities that repatriation presents.

What these difficulties show is that the repatriation process takes a lot of time, energy and resources and that it can be quite convoluted. It is important to be realistic about what can be achieved when. This is because unforeseen challenges can arise and take time to resolve and because the negotiation process cannot be dictated by the terms of one party. Adversarial approaches to repatriation are common and are prone to being affected by the personal views of people involved as they start from a position of suspicion towards repatriation. Increasingly people are seeing that repatriation can result in benefits to all involved. That Karanga Aotearoa is responsible for all international returns of kōiwi tangata to New Zealand helps to address some of these common difficulties. Museums with guidelines about how to respond to international repatriation requests often require that claims have the support of a national government, so Karanga Aotearoa's government mandate allows it the authority to negotiate with institutions. The fact that it is well-resourced means that it can plan for the future and can maintain strong connections with people who have been involved in the repatriation process. Herewini (2011) explains that because the programme's funding will continue for the next few years, it is possible to do strategic planning of how best to utilise that money and to identify areas of priority for their work. One of these priorities is provenance research for repatriated kōiwi tangata, which will help to return them to their iwi. 


\section{The next big issues}

For the Karanga Aotearoa staff, the most important goal of the process is to return kōiwi tangata to their iwi. For this reason, the issue of what to do with unprovenanced kōiwi tangata is the biggest challenge involved in the work. Provenance research tries to track the entire journey of kōiwi tangata from the time they originally left the country. Although some collectors and museums kept good provenance records, in other cases, kōiwi tangata might have changed hands a number of times before entering a museum collection or their location might be recorded as simply "New Zealand", making the trail run cold. For example, provenance research for the kōiwi tangata repatriated from the British Museum has focused on Meinertzhagen's collection activities, but found that there is not enough information to say with certainty where they are from. Generally, Toi moko are more difficult to provenance because history might record the original point of trade, but this is not the same as where they need to be returned to, since they were only traded by enemies. Because of the challenges in establishing provenance for all kōiwi tangata and Toi moko, there are several options being considered for what to do with those that cannot be provenanced. Firstly, it is possible that new forms of research, in addition to the academic and oral history work that is currently being done, will be utilised to determine provenance for Toi moko. These methods might be scientific, such as DNA testing or isotopic analysis, or they might involve further research into the tattoo designs, to possibly identify if there are regional tattooing styles or if certain tattoos can be associated with particular tattoo artists or historical periods (Herewini 2011). Secondly, hui (meetings) are currently being undertaken to assess the views of Māori in relation to options for a final resting place for unprovenanced remains. These options include interment in a specially constructed mausoleum, ongoing storage within Te Papa's wāhi tapu, or reburial near Te Rerenga Wairua at the extreme north of the country, following an offer from the iwi Ngāti Kuri to make land available for this purpose. It is hoped that this issue will be resolved within the next three to four years (Herewini 2011).

So far, discussion has focused on the repatriation of kōiwi tangata, but the repatriation of taonga is also an important issue for many Māori. McCarthy (2011, 216-221) points out that there is a drive among Māori to have taonga returned to the spiritual, as well as the physical, care of their descendent communities, which museums will need to resolve as best they can. Currently, most cases of taonga repatriation occur through the Treaty of Waitangi claims process or through proof that the circumstances in which they came to the museum are 
questionable (McCarthy 2011, 217). However, historically, fears that repatriation in one case will open the floodgates for further repatriation claims have proved unfounded. For instance, Butts notes that there was concern in New Zealand that there would be widespread repatriation requests following the Te Māori exhibition in the 1980s, but this did not eventuate (Butts in McCarthy 2011, 217; see also Tapsell 1998, 148-149).

Rather than increasing the likelihood that all taonga will be removed from museums, repatriation of kōiwi tangata and honest engagement with Māori values foster trust that can increase Māori approval of museums. Discussing the decision-making process at Tairāwhiti Museum, the Museum's previous director, Mike Spedding, explains that it was put to him that "unless their views were taken seriously, Māori might remove collections and develop some alternative museum-like facilities" (Spedding in McCarthy 2011, 163). In this case, their views were taken seriously, and Tairāwhiti Museum has made changes to its governance structure. Furthermore, Tairāwhiti Museum has adopted a policy of voluntary repatriation, in which they return taonga from other iwi to their local museums and hope that this is responded to in kind (McCarthy 2011, 172). Butts $(2003,265)$ notes that Tairāwhiti Museum's willingness to repatriate a patu pounamu (greenstone club) to Te Aitanga-ā-Hauiti in Tolaga Bay in 1999 has led to the strengthening of the relationship between the museum and Te Aitanga-ā-Hauiti. According to Spedding (in Butts 2003, 305) the museum's governance changes and the repatriation of this patu have improved perceptions of the museum generally among Māori. He notes that they have led to people feeling that the museum is approachable and that they can now enter the museum (Spedding in Butts 2003, $305)$.

\section{The importance of relationships}

Much of the literature on repatriation points to the fact that it can result in relationships between the museums or the museum and source community that are rewarding for both parties (see for instance Hubert and Fforde 2002; Peers and Brown 2003; Peers 2003; Scott and Luby 2007, Hole 2007; Gabriel 2009; Wilson 2009; Bienkowski forthcoming). These benefits include sharing knowledge and research about the human remains or objects that have been repatriated or other items that the repatriating museum has retained in its collection. 
Through their government mandate, the Karanga Aotearoa Repatriation Programme has a responsibility to keep iwi involved in the repatriation process. Mamaku (2011) explains that:

We need to keep on communicating with iwi, in terms of updating them on what's been carried out, what we have in Te Papa and what's currently going back to iwi and what's been returned to iwi and what's been brought back from overseas. That's our responsibility that we have to iwi.

In part, this responsibility is achieved through the involvement of the Repatriation Advisory Panel, who can keep iwi informed of the work of the team. Additionally, as soon as it is known that there are human remains in the wāhi tapu belonging to a particular iwi, that iwi is notified (Aranui 2011). Likewise, iwi are informed at the earliest opportunity if there are kōiwi tangata or Toi moko coming back from overseas that are provenanced to their iwi (Herewini 2011). In the future, Herewini hopes that it will even be possible for representatives of an iwi to travel to international repatriation ceremonies if it is known that the tūpuna returning are from their iwi. Herewini (2011) explains why he would like an iwi's own kaumātua to be involved in ceremonies held overseas:

Because [if] they are Moriori, for me it is appropriate that you have kaumātua from the Moriori doing all the rituals and ceremonies and acknowledgements... because it is their ancestors... What I want to do is start to connect those repatriations overseas directly with the iwi they come from by taking representatives of those iwi over to collect them.

In cases where there is good provenance, linking the iwi and the repatriating institution involved in this way will develop Karanga Aotearoa's work by creating more of a connection between the domestic and international sides of their programme. Although there is no mandate requirement for Karanga Aotearoa to continue communication with repatriating institutions, this does occur. Once kōiwi tangata have been repatriated to an iwi, Karanga Aotearoa will send a report to the repatriating institution to let them know what has happened and share research about the kōiwi tangata (Aranui 2011). Additionally, they send them their newsletter on a regular basis to keep them up-to-date with their work (Aranui 2011).

In the experience of Karanga Aotearoa staff, there are three ways that relationships with iwi or other institutions can start. In the most common case, Karanga Aotearoa contacts iwi to let them know about kōiwi tangata held in the wāhi tapu or they contact other institutions to establish if they have kōiwi tangata in their collection and negotiate repatriation from there. 
Secondly, an iwi group or institution might initiate contact with Karanga Aotearoa specifically to discuss repatriation. This was the case in the repatriation of the Toi moko from Rouen. Aranui (2011) notes that while these approaches are "fantastic" they do not happen frequently. Finally, the relationship might be established for a reason other than repatriation, such as arranging an exhibition or loan, and will be passed to Karanga Aotearoa if repatriation is a possibility. For instance, the return of "Number One Woman" to Rangitāne o Wairau for reburial, which later led to the repatriation of the second Wairau Bar tupuna, began when taonga were loaned to the Millennium Art Gallery in Marlborough for exhibition. In 2011, a loan request of waka huia (feather boxes) and huia feathers was put to the Museum fur Völkerkunde in Vienna. The Museum loaned these items to Te Papa and representatives came to the opening of the Tainui exhibition in September that year. According to Herewini (2011) because of the cultural exchange that occurred, the Museum fur Völkerkunde staff shared information about one Toi moko in their collection and were willing to discuss the future possibility of repatriation.

The relationships that lead to repatriation can be longstanding before repatriation occurs. For instance, the relationship between Te Papa and the Field Museum in Chicago initially developed during the Te Mãori exhibition in the 1980s. As this relationship progressed, Te Papa staff went to the Field Museum to help with the refurbishment of the wharenui, Ruatepupuke II, and provide information about taonga in their collection. This led to the repatriation of kōiwi tangata in 2007 (Herewini 2011). Similarly, Auckland Museum's repatriation project began when organising the Ko Tawa exhibition, and their earlier repatriations to Ngā Puhi developed out of their collaboration about taonga in the Museum (see McCarthy 2011, 160).

Despite their importance, when repatriation is complete, relationships might not remain active. Herewini (2011) explains that:

A lot of the curators in the museums or the collection managers have a lot of influence, and I believe that they feel very strongly that the kōiwi tangata or Toi moko should return, so they have an active role in negotiating the return within the museum and within their respective authorities and also with Te Papa. I think for them, in those sorts of situations, by returning the tūpuna home they feel they have done the right thing, but they also feel that their responsibility has ended because they have returned the tūpuna. So that's where you can maintain a connection and a relationship, but it is not necessarily active. 
In relation to these inactive relationships, Aranui (2011) explains that the team often forms good relationships with individuals which then continue over the years, although this may not necessarily be related to repatriation. By sending their newsletter to iwi and institutions they have been involved with, Karanga Aotearoa maintains these connections. Karanga Aotearoa has a short-term role in ongoing relationships between Te Papa and iwi or institutions. Relationships with iwi are maintained in the long term by the Iwi Relationships team, a separate team within Te Papa. At Auckland Museum, repatriation has not yet led to any additional projects between the Museum and iwi (Vodanovich 2011). However, Herewini (2011) notes that in inactive cases "the relationship has never ended, it is just that when we have to interact again, we will". This shows that there is not a fast or direct transition from repatriation to the cooperative projects that are often cited as outcomes of repatriation, but the connections formed can be called on when opportunities arrive.

Although beneficial relationships are stressed as an outcome of repatriation, they can exist without successful repatriations having occurred or in situations where the outcome was less than ideal. The Field Museum and Te Papa co-operated successfully for twenty years before repatriation occurred, as described above. Similarly, the British Museum and Te Papa have a long-standing relationship and have recently collaborated for the publication of two books about the British Museum's collections, the first about their Pacific collections and the second about their Māori collections (Herewini 2011). This is despite the disappointing result of Karanga Aotearoa's repatriation negotiations with them. Furthermore, during the initial negotiations about the return of the Toi moko from the Natural History Museum in Rouen, Karanga Aotearoa were eager to contact the Quai Branly Museum before the repatriation was made public. This was because they had a pre-existing relationship with the Quai Branly Museum, who were disinclined towards repatriation at that time.

The strength of relationships is critical to successful repatriation negotiations, whether they are developed prior to or during the repatriation process. Knowledge transfer about these relationships is critical because they are embodied in particular individuals. Tapsell (2011) explains that when staff are replaced, new staff have to re-build a rapport and trust with communities:

When you do go back to these places you've visited and your... people are now gone, you start all over again because it's about the relationship. You're in that community. You're 
a new face. They don't see [the institution] they see you, so everything swings on your ability to be able to communicate the values and the importance [of repatriation].

However, because of the emotive nature of repatriation and because so much of the repatriation process involves only a few key individuals, the sense of personal responsibility they feel towards their projects and the iwi they engage with can be massive. Vodanovich (2011) explains that:

I think it takes quite a personal toll on people doing it too. I think that the other thing that maybe is underestimated is the personal burden that people like Rangiiria take on taking on that task and the personal responsibility that they feel I think is quite huge.

Similarly, Wyllie (2011) explains that he "found Ringatū prayers helped enormously with the work because it's quite a heavy burden when you're the only staff member out of eleven staff and while everyone else is at work you're out in the country with a spade burying people...". Karanga Aotearoa Co-ordinator, Te Arikirangi Mamaku (2011), explains the significance of Karanga Aotearoa's responsibility and how this impacts their process:

It's a slow but considered process. It is significant because we're responsible for making sure that these tūpuna are taken back and are basically laid to rest. We need to be without doubt that what we're doing and where we're taking them and how we're going about our work is dignified and that is the important thing and we just do our best.

Relationships are an integral part of the repatriation process. Most literature points to the benefits of repatriation, such as research exchange or exhibition collaborations, as being a product of the relationships established during the repatriation process. While these benefits can occur in this way, rewarding relationships can pre-date repatriation or can exist when unsuccessful or semi-successful repatriation negotiations have occurred. This is because, as Carroll (2008) concludes, relationships are now at the heart of museum practice. The way that Karanga Aotearoa staff understand their responsibility to iwi epitomises Peers and Brown's (2003) source communities approach, which sees museums as stewards of collections for their originating community. The Karanga Aotearoa team consider that iwi have authority for the kōiwi tangata in Te Papa's collection and that it is their duty to facilitate the repatriation process in an open and dignified way. 


\section{Museum practice}

Museum practice has developed in response to increased community engagement, and repatriation efforts are a part of this. In New Zealand, this has partly been a response to the Treaty of Waitangi settlement process, which has forced museums to think about the way they involve Māori and has resulted in governance changes and repatriation. Internationally, there is still some apprehension towards repatriation, as it represents a fundamental shift in the way museums operate.

Some museum professionals continue to resist repatriation on principle, seeing it as a threat to what they consider to be the purpose of museums - to preserve collections intact for future generations. As repatriation claims have become more common, critics have developed responses to it, including adversarial repatriation processes. Adversarial repatriation processes, although heavily weighted against repatriation, make it appear that museums are at least considering repatriation with open minds, and if repatriation is refused, it is done so with the argument that it is not in the public interest of the world's peoples. However, Besterman $(2006,431)$ points out that although museum professionals do have a duty of care to collections, this duty only has meaning within the context of human interaction because ethics concerns social responsibility (Besterman 2006, 431). This means that ethical practice relates to a museum's relationship with people, rather than things as is more traditionally thought (Besterman 2006, 431). He argues that possession and interpretation of material culture raise sensitive issues of "representation" and "ownership", but that through an ethical framework that puts relationships with people first "museums have an opportunity to reflect, respect and nourish the human spirit as well as intellect, and to celebrate different ways of seeing, studying, and comprehending the world" (Besterman 2006, 440). Similarly, Bienkowski (forthcoming) argues that the purpose of museums should be to foster understanding between the world's peoples and to be a forum for discussing the meanings of objects. This, he says, is not achieved through adversarial repatriation processes, which only limit dialogue and understanding by assuming that repatriation is wrong and subjecting the claimants to legitimacy tests they find offensive.

While some museums internationally are developing policies that limit repatriation, others are increasingly embracing it. In some cases, though, it is necessary for some sort of legal or moral imperative to exist which forces museums to examine their collection practices and 
accept repatriation as the right thing to do. For instance, prior to the law change, there was a lot of resistance to repatriation in French museums. As mentioned, Quai Branly Museum was among those opposed to repatriation. The law change was French-led, but forced museums to repatriate Toi moko, even when they might have been reluctant to. The new law does not apply to Toi moko in university collections, so the two universities with Toi moko could choose to take part. Whereas one university, the University of Montpellier, did participate in the repatriation, the second did not, suggesting some resistance to repatriation still exists in France. In contrast, French museums have had no choice but to accept the change, however the shift in Quai Branly Museum's attitude shows that those that might have been opposed are willing to embrace the possibilities repatriation will present. In New Zealand, there is no law requiring museums to repatriate kōiwi tangata. However, repatriation is facilitated in part by the Treaty of Waitangi settlement process and there is now a strong sense that it is the proper course of action.

Since the 1970s, Treaty of Waitangi settlements have sought to redress Crown breaches of the Treaty's principles. Desecration of Māori burial sites and the collection of kōiwi tangata can be seen as a breach of these principles. Particular repatriation cases are sometimes borne out of, or at least connected to, individual Treaty claims. For instance, in their Treaty settlement, Rangitāne o Wairau were returned an area of the Wairau Bar specifically for the reinterment of repatriated tūpuna. The Treaty's relevance to repatriation is not limited to kōiwi tangata, as the return of the wharenui Te Hau ki Türanga from Te Papa to Gisborne has recently been agreed to (see McCarthy 2011, 217-218). Additionally, the fact that the government decided to mandate Karanga Aotearoa to undertake repatriation work can be viewed in the context of the Crown trying to honour the Treaty and redress the past.

As well as affecting race relations and politics, the Treaty settlement process has had an effect on museum practice, as museums have increasingly incorporated the principle of partnership and collaboration with Māori at a legislative level. Frequently, the repatriation of kōiwi tangata has been preceded by such legislative cases, as seen, for example, in the Chapter One cases of Auckland Museum and Tairāwhiti Museum. Through increased Māori involvement, museums have realised that they need to change the persistent view that they are urupā or places for "stealing taonga", as participants in Canterbury Museum's repatriation 
to Rangitāne o Wairau charged (McCarthy 2011, 220). ${ }^{21}$ Tapsell $(2005,167)$ explains the importance of changing this view:

... until the continuing custody of kōiwi is redressed, sustainable engagement with Māori will remain illusive [sic]. So long as museums continue to hold their ancestors, Māori communities will remain uncomfortable developing relationships with museums like Auckland, lest they be perceived to be aiding and abetting the status quo of ancestral capture.

Because of this, to show they are serious about listening to Māori concerns and are willing to change, New Zealand museums have had to address the question of kōiwi tangata in their collections. How they should address this question, though, has presented a learning curve for museum staff used to having full control of museum collections. Carroll $(2008,4)$ argues that museums have, historically, thought that once something was added to their collection it was exclusively their property. According to this model, items entered museum collections through one-off transactions that did not imply or establish any sort of ongoing reciprocal relationship between the museum and the donor or seller. Vodanovich (2011) explains that there is danger in museums continuing to believe they can operate on transactions, especially when dealing with repatriation:

You can't just hand-over and run. I think that is really challenging for museums because museums operate on transactions largely - well, traditionally, I should say - and the world more and more operates on relationships, which last beyond a transaction and that all takes time and resources and commitment and it's definitely something that's challenging, I think.

This suggests that museums need to adapt from their transactional operational models to recognise the importance of long-term relationships, and to recognise the need to resource them properly. By moving away from the old transactional model, repatriation can be seen as a type of "contact zone", as it acknowledges that there is a historical, political and moral relationship between museums who have human remains and their descendent communities (Clifford 1997).

Additionally, museums need to realise that repatriation negotiations can take a considerably long time. Because of this, making repatriation efforts fit within museum business models that require the achievement of certain targets in a set time frame simply will not work.

\footnotetext{
${ }^{21}$ The view of museums as urupā is mentioned in McCarthy $(2011,216)$ and Tapsell $(2005,167)$.
} 
Rather, repatriation requires an approach that is altogether more flexible and accommodating. Such a flexible approach is a marked departure from the old "transaction" model, which is no longer workable because people expect a level of community engagement.

Museum practice has been expanded through repatriation. Rather than resulting in everything being removed from museums, it has helped museums to develop beneficial partnerships. The issue of repatriation does cut to the heart of what a museum ought to be and some museums continue to resist it for this reason, rather than accepting their museum practice might need to change. Legislative or moral requirements for repatriation force museums to reconsider their practice. In New Zealand, through the Treaty of Waitangi settlement process and, correspondingly, increased Māori involvement at museum governance level, museums have recognised the importance of repatriation. Repatriation represents a departure from the traditional "transaction" model of museum practice to a "contact zone" approach, as it requires that museums engage with communities on an ongoing basis. This new model requires that museums invest resources in long-term community engagement and adopt a flexible approach to repatriation.

\section{Conclusion}

Repatriation of human remains will continue to be a major issue in both New Zealand and abroad. As repatriation increases, museums will have to develop their practice to recognise that it requires a different approach to the traditional one in which relationships last only for one transaction. Instead there must be commitment to long-term engagement with the communities museums deal with. On a purely practical level, what makes repatriation successful are the same things that make anything successful - time, money and dedicated people making things happen. Part of what makes the Karanga Aotearoa Repatriation Programme successful is that these three things are guaranteed, allowing staff the ability to do their jobs effectively and navigate unforeseen challenges with flexibility. This means that the team can foster ongoing relationships with people and institutions involved in repatriation, from which further benefits can arise. Additionally, success in repatriation negotiations requires that museums recognise that source communities have legitimate interests in museum collections, as Peers and Brown (2003) suggest, and are willing to engage with these concerns in a meaningful way. This movement away from the old idea that museum practice is pre-eminent and fixed to a more flexible approach that acknowledges 
that museums do not have all the answers but are willing to learn and are serious about change is a necessary step. By taking this step, museums will be better able to maintain their relevance and will be in a better position to interpret their collections through having increased access to knowledge about them. This is because while relationships are now the heart of museums, ethical practice and honest, humble and open-minded engagement with other people's values ought to be its soul. Only that philosophy will allow museums to fulfil their purpose to serve people and continue to be centres for learning, discourse and cultural exchange. 


\section{Conclusion}

In this conclusion, I review the findings of this study by chapter, make recommendations for future research, and comment on the contribution of the research to museum studies and the museum sector. This research aimed to address a gap in the literature concerning repatriation practice, by answering the question, "How are problems in the repatriation process overcome to create mutually rewarding relationships between museums and others involved in the repatriation of human remains?" This question can be broken into two parts for discussion, which are: what problems can arise in the repatriation process; and how are these issues overcome. Briefly, I also consider the nature of the "mutually beneficial relationships" that can result from repatriation, before moving on to the areas of future research and the contribution of the research.

Chapter One provided background to the New Zealand trade of human remains between 1770 and 1988 and discussed the repatriation projects of three museums, showing how they acquired human remains in the first place, how they came to consider repatriation and what steps they took to organise their repatriation projects. In each case, repatriation followed changes in the museums' legislation and the nature of their relationships with Māori communities. None of the projects discussed could be described as "straightforward". In Chapter Two, I looked at the work of the Karanga Aotearoa Repatriation Programme in three repatriation cases to further see how repatriation can be complex in practice. These cases show that unforeseen difficulties can arise in even the most amicable negotiations. Chapter Three expanded upon some of the problems experienced in the Chapter Two examples, analysing the major difficulties that New Zealand museum professionals feel impact their work and how they can be dealt with.

Problems are an inherent part of the repatriation process. I found common challenges shared by New Zealand museum professionals working in repatriation basically fall into two broad areas; logistical and ideological challenges. Logistical challenges relate to finding the time, resources, and energy to undertake repatriations and commit to long-term engagement with iwi. Ideological challenges relate to sensitivities around human remains that might mean people do not want to discuss repatriation, and people or institutions being opposed to 
repatriation on principle. Unclear policies or concepts are more easily manipulated by those who do not support repatriation, and are an extra hurdle to overcome.

The ways in which these problems are resolved is through more time and more resources, even though finding these is itself a challenge. The approach that works best to overcome difficulties in the repatriation process is flexibility with dedicated staff. It is necessary to adequately fund a repatriation process, allowing staff to navigate tricky negotiations or unforeseen problems effectively, without antagonism, and with the understanding that it takes as long as it takes.

The strength of relationships between negotiating parties is important in the repatriation process. Although these relationships might not be "active" once repatriation has been completed, they can be called on in future either again regarding repatriation, as was the case with Rangitāne o Wairau and the Karanga Aotearoa Repatriation Programme, or for something new such as exhibition collaboration. However, beneficial relationships can exist outside of repatriation occurring and this is an increasingly important facet of museum practice. For instance, the British Museum and Te Papa have a successful collaborative relationship even though the outcome of their repatriation negotiations was less than Karanga Aotearoa had hoped for.

As repatriation establishes ongoing relationships based on the recognition that holding institutions do not have exclusive interest in the human remains in their collections, repatriation practice can be seen as a "contact zone". Clifford $(1997,192)$ suggests that museum collections establish a "historical, political, [and] moral relationship" between the museum and the people from whom they get their collection. This is a similar claim to Peers and Brown's $(2003,8)$ that museums have an ethical obligation to include source communities in decisions about their heritage. This obligation is based on the ideas that: source communities have special interests in museum collections; an ongoing relationship is established with a source community when something enters a collection; and ethical practice relates to how museums treat people since it is an expression of social responsibility (see Peers and Brown 2003; Clifford 1997; Besterman 2006). Successful repatriation programmes, such as the Karanga Aotearoa Repatriation Programme, acknowledge this responsibility to source communities and enter into repatriation negotiations in an openminded and humble manner, allowing staff to facilitate rewarding partnerships 
A major limitation of this study was that I could not interview more people, owing to time and financial constraints. Because of this, there are some important groups whose thoughts on the repatriation process have not been heard. In particular, it would have been especially beneficial to interview members of the Repatriation Advisory Panel, other Te Papa staff whose jobs bring them into the repatriation process, such as the Iwi Relationships team, and key people who were involved in the repatriation cases I discussed in Chapter Two, such as British Museum staff. It would have been interesting also to hear from a larger number of New Zealand museum professionals, especially those who are less certain of repatriation's worth. Additionally, how iwi feel about the repatriation process and their experiences with museums are missing from this research. This means that there is considerable scope for future research.

Repatriation of human remains is emotive and can be further complicated by confusing or ambivalent laws or policies. For this reason, there is a need to study repatriation from every angle, whether that is ethics, legislation, policy, or repatriation's effect on museum practice. More research into the repatriation process in case studies is required. A comparative study of the methods of one country's approach over another and their relative success would be particularly valuable. As mentioned above, another limitation of my study was that I was unable to include iwi perspectives on repatriation. Few authors have looked into source community experiences of repatriation, Atkinson (2010), Jorgensen (2005), Solomon (2005) and Wilson (2009) being four notable exceptions, but it is likely that further research will provide new insights that will have implications for museum practice. For instance, currently source communities are approached by multiple museums separately, each following their own repatriation process. How effective this is, needs to be investigated. It seems probable that this approach is preferable for museums, but that a coordinated repatriation that includes multiple institutions in one event would better suit source communities' needs. If that is found to be the case, small countries, such as New Zealand, with a relatively small museum sector, would be well-placed to begin large-scale cooperative repatriations, as it would require that museums inventory the remains that they have and share provenance details with each other. That this is possible is demonstrated by France returning all Toi moko in French museums to New Zealand at the same time in January 2012.

There are two other specific studies that I believe are necessary to further understanding of the repatriation process and museum practice. Firstly, there is potential for research into 
whether "science versus repatriation" is at all a fair way to characterise repatriation debate. Frequently, it seems that repatriation is presented as being in complete opposition to the goals of science, encouraging professionals to pick sides. As mentioned in the British Museum and Wairau Bar case studies, scientific investigation was an option pre-repatriation. It is possible that this is a false dichotomy, but that the rhetoric on this issue contributes massively to some museums' apprehension about repatriation, putting them on the defensive which is then seen in their adversarial repatriation processes. Secondly, a study analysing who "universal" museums serve would increase understanding of adversarial repatriation processes. By claiming they serve a generic world population they might limit any real engagement with the concerns of particular groups, allowing them instead to continue to serve only the interests of a Western elite. If true, this has implications for repatriation as it means these museums are unlikely to reflect on the question of whether they ought to retain human remains. The rhetoric around "science versus repatriation" and the values of "universal" museums likely support museums' fear of repatriation, and it would be valuable to understand to what extent they affect the repatriation process.

This research contributes to museum studies and the museum sector in three important ways. Firstly, this research helps to fill the gap around "current practice" in the literature of museum studies, which is especially apparent in the lack of studies on the practice of repatriation. It does this by focusing specifically on the problems that can be encountered during the repatriation process, and how they are overcome. This has been neglected because few authors have been prepared to comment on this aspect of the repatriation process. Secondly, the research has drawn on New Zealand museum professionals' experiences of and insights into the process, as well as detailed actual examples of repatriation negotiations. This will help professionals working in the sector to understand how they might experience repatriation negotiations and prepare as best they can for problems that might occur. Ultimately, the most important contribution this research makes is that it demonstrates that repatriation practice requires a different mode of operation from traditional museum practice. The "transaction" model or the idea that museum practice takes precedence will not do in this situation, which is dependent on relationship building and often progresses very slowly. This type of work requires museum professionals to have understanding, openness and flexibility.

This research has shown that it is possible to overcome problems in the repatriation process to create mutually beneficial relationships. To achieve this, museums need to invest in the 
repatriation process, allowing staff the resources and time to effectively engage with communities and sort through any challenges. To do this in a meaningful way that will facilitate ongoing relationships, museums need to approach the repatriation of human remains with the understanding that source communities matter and have a role to play in the future of museum practice, remaining conscious that "it took years and years and years for museums to get to this place and it might take years and years and years for museums to get back out of it" (Vodanovich 2011). 


\section{Appendix 1: Glossary}

This glossary was prepared with reference to Jorgensen (2005), Tapsell (2005) and the Māori Dictionary Online.

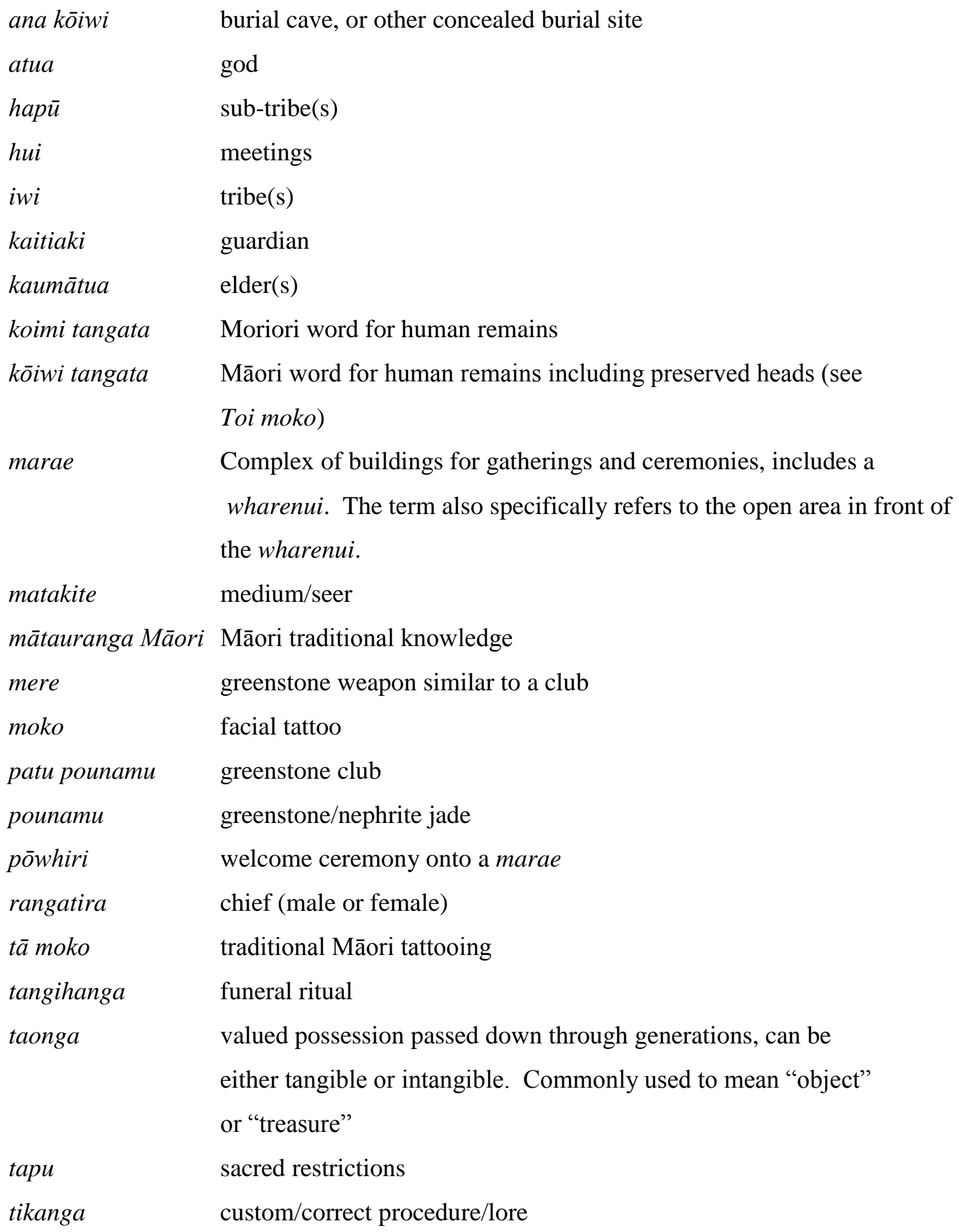


Toi moko

tupuna

tūpuna

urupā

wāhi tapu

waka huia

wānanga

whare kōiwi

wharenui

whare taonga preserved tattooed heads (also known as mokomokai,

mokamokai, uru-moko)

ancestor (singular)

ancestors (plural)

cemetery/burial ground

sacred or consecrated place, such as a burial ground

feather box

seminar(s)

mausoleum

meeting house, main house of a marae

museum, literally "treasure house" 


\section{Appendix 2: Interview guide questions}

- What is your role in the repatriation process for human remains?

- At your institution, what relevant policies exist concerning human remains and their repatriation?

- In what ways do these policies guide the repatriation process?

- What are the stages of the repatriation process that your institution follows?

- What is the role of relationships with source communities in the repatriation process?

- How are relationships with source communities and other institutions formed?

- How are relationships with source communities and other institutions maintained?

- What difficulties can arise during the repatriation process and in what ways are they overcome? 


\section{References}

\section{These references are divided into the following sections:}

A. Primary sources - archival material, electronic sources, museum reports and policies, and interviews.

B. Secondary sources - journal and newspaper articles, books, conferences papers and theses.

\section{A. Primary sources:}

\section{Archival material:}

Archives New Zealand:

Miscellaneous - Mummified bodies of Māori chiefs taken to Vienna. Record number 19/1/547. Archives New Zealand. Wellington.

Karanga Aotearoa Repatriation Programme files:

Harrison, K. 2007. UK Jan 2007 meeting: British Museum London. British Museum file.

Herewini, T.H. 2009. Letter to Richard Bradley, Chief Executive of Rangitāne o Wairau, 17 February. Rangitāne o Wairau file.

Pōmare, M. 1993. Letter to Peter Brown, New Zealand High Commission in London, 4 November.

Smith, N.K. 2009. Notes from meeting with Richard Bradley, 24 February. Rangitāne o Wairau file.

\section{Electronic sources:}

Auckland District Law Society website. 2011. News details: Seeking repatriation of Māori heads has proved difficult. Available at: http://www.adls.org.nz/resources/news-details?NewsId=38ba426b-c4c7-4ab1-8d30328fba042bf 1

Auckland War Memorial Museum Website. History of the Museum. Available at: http://www.aucklandmuseum.com/159/history-of-the-museum 
—. Ko Tawa. Available at: http://www.aucklandmuseum.com/90/ko-tawa

British Museum website. Human remains: Request for repatriation of human remains to New Zealand. Available at:

http://www.britishmuseum.org/the_museum/news_and_press/human_remains/repatria tion_to_new_zealand.aspx

—. Human remains: Request for repatriation of human remains to Tasmania. Available at:

http://www.britishmuseum.org/the_museum/news_and_debate/debate/human_rem ains/repatriation_to_tasmania.aspx

Māori Dictionary Online. Available at: http://www.maoridictionary.co.nz/

Musées en Haute-Normandie website. Available at:

http://musees-hautenormandie.fr/fiche.php3?lang=en\&id_article=1424

Museum of New Zealand Te Papa Tongarewa website. Domestic repatriations. Available at: http://www.tepapa.govt.nz/AboutUs/Repatriation/Pages/DomesticRepatriations.aspx

- International repatriations. Available at: http://www.tepapa.govt.nz/AboutUs/Repatriation/Pages/InternationalRepatriations.as px

- Our history. Available at:

http://www.tepapa.govt.nz/AboutUs/history/Pages/default.aspx

New Zealand Ministry of Culture and Heritage Manatū Taonga website. New Zealand welcomes 20 ancestors home. Published 23 January 2012. Available at: http://www.mch.govt.nz/news-events/news/new-zealand-welcomes-20-ancestorshome

Te Ara The Encyclopaedia of New Zealand website. Robley, Major-General Horatio Gordon. Originally published in A.H. McLintock, A.H. ed. An Encyclopaedia of New Zealand 
(Wellington: New Zealand Government,1966). Available at:

http://www.teara.govt.nz/en/1966/robley-major-general-horatio-gordon/1

\section{Museum reports and policies:}

Aranui, A. 2009. Meinertzhagen collection of kōiwi tangata repatriated from the British Museum, 2008. Karanga Aotearoa Repatriation Programme, The Museum of New Zealand Te Papa Tongarewa. Unpublished.

Auckland Museum Trust Board. 2008. Human Remains Governance Policy. Auckland Museum. Available at:

http://www.aucklandmuseum.com/site_resources/library/Top_Menu/About_Us/Gover nance_Policies/07Human_Remains.pdf

Auckland Museum Collection Manager. 2008. Human Remains Operating Policy. Auckland Museum.

Bennington, S. 2007. Letter to Andrew Burnett from Seddon Bennington 20/01/07. In "Request for the repatriation of human remains by Museum of New Zealand Te Papa Tongarewa: Dossier," 45-46. Available at:

http://www.britishmuseum.org/pdf/00\%2017\%20Te\%20Papa\%20letter\%20to\%20AB \%2020.01.07.pdf

Besterman, T. 2005. Report for the Trustees of the British Museum: Request from the Australian Government for the return of two cremation ash bundles from Tasmania. In "Final dossier", 12-32. Available at: http://www.britishmuseum.org/pdf/Final_Dossier.pdf 2007. Report to the Board of Trustees of the British Museum: Request from Te Papa for the return of sixteen Māori kōiwi tangata to New Zealand. In "Request for the repatriation of human remains by Museum of New Zealand Te Papa Tongarewa: Dossier," 69-101. Available at: http://www.britishmuseum.org/pdf/00\%2022\%20Tristram\%20Besterman\%20report\% 20dated\%20April\%2007.pdf 
Bolton, L. 2007. Repatriation request from Karanga Aotearoa (Repatriation Unit), Te Papa Tongarewa (Museum of New Zealand): Report on discussions held in New Zealand. In "Request for the repatriation of human remains by Museum of New Zealand Te Papa Tongarewa: Dossier,” 108-115. Available at: http://www.britishmuseum.org/pdf/00\%2026\%20Lissants\%20Report\%20to\%20Trust ees.pdf

British Museum. 2006a. Final dossier. British Museum. Available at: http://www.britishmuseum.org/pdf/Final_Dossier.pdf 2006b. The British Museum policy on human remains. British Museum. In "Request for the repatriation of human remains by Museum of New Zealand Te Papa Tongarewa: Dossier," 3-10. Available at: http://www.britishmuseum.org/pdf/Human\%20Remains\%206\%20Oct\%202006.pdf 2006c. Human remains from New Zealand: Briefing note for Trustees. In "Request for the repatriation of human remains by Museum of New Zealand Te Papa Tongarewa: Dossier," 29-39. Available at: http://www.britishmuseum.org/pdf/00\%2012\%20Briefing\%20note\%20to\%20Trustees \%20dated\%2023.11.06.pdf 2007. Meinertzhagen collection of 1895. In "Request for the repatriation of human remains by Museum of New Zealand Te Papa Tongarewa: Dossier,” 117-121. Unpublished.

Cabinet Policy Committee. 2003. Government policy for the repatriation of kōiwi tangata Māori (Māori human remains). Wellington: Cabinet Office. Unpublished.

Endicott, P. 2007. Report on the prospects and potential value of scientific research on human remains from New Zealand held in the British Museum. In "Request for the repatriation of human remains by Museum of New Zealand Te Papa Tongarewa: Dossier," 47-65. Available at: http://www.britishmuseum.org/pdf/00\%2018\%20Philip\%20Endicott\%20Report.pdf 
Foley, R. 2007. Comment on Besterman report by Robert Foley. In "Request for the repatriation of human remains by Museum of New Zealand Te Papa Tongarewa: Dossier," 105-107. Available at: http://www.britishmuseum.org/pdf/00\%2025\%20Rob\%20Foley\%20comment\%20on \%20British\%20Museum\%20Endicott\%20report.pdf

Hakaraia, H. 2005. The Karanga Aotearoa Repatriation Programme. The Museum of New Zealand Te Papa Tongarewa. Available at: http://www.tepapa.govt.nz/SiteCollectionDocuments/AboutTePapa/Repatriation/Kara nga\%20Aotearoa\%20Resources.pdf

Karanga Aotearoa Repatriation Programme. 2009a. Wairau kōiwi tangata. The Museum of New Zealand Te Papa Tongarewa. Available at: http://www.tepapa.govt.nz/SiteCollectionDocuments/AboutTePapa/Repatriation/Rang itāne o WairaukiWairauRepatriationReportApr09.pdf

- 2009b Summary Document. The Museum of New Zealand Te Papa Tongarewa. Available at: http://www.vastarvet.se/upload/vastarv/Dokument/2009\%20Nov\%20Te\%20Papa\%20 Summary\%20Background\%20Repatriation.pdf 2010. Tairāwhiti hui ā rohe report. The Museum of New Zealand Te Papa Tongarewa. Available at: http://www.tepapa.govt.nz/SiteCollectionDocuments/AboutTePapa/Repatriation/Taira whitiHuiaRoheReport.pdf

- 2011. Press release information. The Museum of New Zealand Te Papa Tongarewa. Available at: http://www.tepapa.govt.nz/SiteCollectionDocuments/Media/2011/European_Repatriat ion_Background_info_for_Press_Releases_-_29_April_to_12_May_2011.pdf 
2012. Background Document January 2012. The Museum of New Zealand Te Papa

Tongarewa. Available at:

http://www.mch.govt.nz/files/437839-

Te\%20Papa\%20Repatriation\%20Programme\%20Jan\%202012.doc

Te Puni, J. 2006. Letter to Lissant Bolton from James Te Puni 12/04/06. In "Request for the repatriation of human remains by Museum of New Zealand Te Papa Tongarewa: Dossier," 15-16. Available at:

http://www.britishmuseum.org/pdf/00\%2004\%20Te\%20Papa\%20to\%20LB\%2012.04 .06.pdf

The Museum of New Zealand Te Papa Tongarewa. Kōiwi tangata policy: Summary information. The Museum of New Zealand Te Papa Tongarewa. Available at: http://www.tepapa.govt.nz/SiteCollectionDocuments/AboutTePapa/Repatriation/Koi wiTangataPolicy_PublicInfo_Summary.pdf

\section{Interviews:}

Aranui, Amber. November 2011.

Mamaku, Te Arikirangi. November 2011.

Herewini, Te Herekiekie. November 2011.

Tapsell, Paul. September 2011.

Vodanovich, Laura. September 2011.

Wyllie, Jody. August 2011.

\section{B. Secondary sources:}

Amiel, O., Translated by Marine Bel and Michael Berger. 2008. "A Māori Head: Public Domain?" International Journal of Cultural Property 15: 371-375

Atkinson, H. 2010. "The meanings and values of repatriation." In The long way home: The meaning and values of repatriation, edited by Paul Turnbull and Michael Pickering, 15-19. New York: Berghahn Books 
Auckland Institute and Museum. 1878. Annual Report of the Auckland Institute and Museum. Auckland: Auckland Institute and Museum

BBC News. 2011. "France hands back Māori mummified head to New Zealand." BBC News Asia-Pacific, 9 May. Available at: http://www.bbc.co.uk/news/world-asia-pacific-13329600

Bel, M., Michael Berger, and Robert K. Paterson, 2008. "Administrative Tribunal of Rouen, Decision No. 702737, December 27, 2007 (Māori Head case).” International Journal of Cultural Property 15: 223-226

Besterman, T. 2006. "Museum ethics.” In A companion to museum studies, edited by Sharon Macdonald, 431-441, Oxford: Wiley-Blackwell

—. 2008. "Why the British Museum should give back Māori human remains if it wants to take a truly enlightened approach.” Museums Journal July 2008: 17

Bienkowski, P. Forthcoming. "You're gonna make me lonesome when you go: A critique of restitution and repatriation practices." In Museum practice: Critical debates in contemporary museums, edited by Conal McCarthy, Malden MA: Blackwells, 2013

Blackie, N. 2000. "Research questions and objectives." In Designing social research: The logic of anticipation, 58-84. Malden, MA: Polity Press

Burnett, A. 2008. "Why it is sometimes ok to say no to requests for the return of human remains." Museums Journal June 2008: 17

Butts, D. 2002. "Maori and museums: The politics of indigenous recognition." In Museums, society, inequality, edited by R. Sandell, 225-243. London: Routledge

—. 2003. "Māori and museums: The politics of indigenous recognition." $\mathrm{PhD}$ thesis, Massey University 
2007. "Maori, museums and the Treaty of Waitangi: The changing politics of representation and control." In Museum revolutions: How museums change and are changed, edited by Simon J Knell, Suzanne Macleod and Sheila Watson, 215-227. New York: Routledge

Carroll, R.A. 2008. "The acquisition of the Partington Collection by Whanganui Regional Museum: Valuing relationships in museum policy and practice.” MA diss., Massey University

Clifford, J. 1997. Routes: Travel and translation in the late Twentieth Century. Cambridge, Massachusetts: Harvard University Press

Cubillo, F. 2010. "Repatriating our ancestors: Who will speak for the dead?" In The long way home: The meaning and values of repatriation, edited by Paul Turnbull and Michael Pickering, 20-26. New York: Berghahn Books

Daily Mail Reporter. 2011. "Māori warrior's head returned to New Zealand after 136 years in French Museum.” Mail Online, 9 May. Available at: http://www.dailymail.co.uk/news/article-1385165/Mummified-Māori-head-handedNew-Zealand-136-years-French-museum.html

Davis, J.B. 1867. Thesaurus craniorum: Catalogue of the skulls of the various races of man in the collection of Joseph Barnard Davis. London: Printed for the subscribers.

Fforde, C., Jane Hubert and Paul Turnbull (eds). 2002. The dead and their possessions: Repatriation in principle, policy and practice. London: Routledge

Fforde, C. 2004. Collecting the dead: Archaeology and the reburial issue. London: Duckworth

Field, C. 2007. "French to send home head of warrior." New Zealand Herald, 23 October.

Gabriel, M. 2009. “The return of cultural heritage from Denmark to Greenland.” Museum International 61(1-2): 30-36 
Gill, B. 2010. "The Cheeseman-Giglioli correspondence, and museum exchanges between Auckland and Florence, 1877-1904." Archives of Natural History 37(1): 131-149

Gregory, A. 1999. "Renowned warriors home after 160 years." New Zealand Herald, 3 April.

Haast, H.F. von. 1948. The Life and Times of Sir Julius von Haast, K.C.M.G., Ph. D., D. Sc., F.R.S. : explorer, geologist, museum builder. Wellington: The author

Hemming, S., and Chris Wilson. 2010. “The first 'Stolen Generations': Repatriation and reburial in Ngarrindjeri Ruwe (country)." In The long way home: The meaning and values of repatriation, edited by Paul Turnbull and Michael Pickering, 183-198. New York: Berghahn Books

Herewini, T. H. 2008. "The Museum of New Zealand Te Papa Tongarewa (Te Papa) and the repatriation of koiwi tangata (Maori and Moriori skeletal remains) and Toi moko (mummified Maori tattooed heads)." International Journal of Cultural Property. 15: 405-406

Hole, B. 2006. "Loose notions about heads: The repatriation of human remains in New Zealand.” MA diss., Birkbeck College -2007. "Playthings for the foe: The repatriation of human remains in New Zealand." Public Archaeology 6(1): 5-27

Holmes, R. 2007. African Queen: the real life of the Hottentot Venus. New York: Random House

Hubbard, C. 2005. "Moa hunter home.” Stuff National News 17 June. Previously available at: http://www.stuff.co.nz/stuff/0,2106,3317108a8153,00.html. Accessed 30 June 2006.

Hubert, J., and Cressida Fforde. 2002. Introduction to The dead and their possessions: Repatriation in principle, policy and practice, edited by Cressida Fforde, Jane Hubert and Paul Turnbull, 1-16. London: Routledge 
Hunt, T. 2012. "Toi moko arrive at Te Papa." The Dominion Post, 27 January. Available at: http://www.stuff.co.nz/dominion-post/news/6322514/Toi-moko-arrive-at-Te-Papa

King, M. 2003. Penguin history of New Zealand. Auckland: Penguin Books

Le Pla, R. 2009. “The homecoming.” Heritage New Zealand. Spring 2009. Available at: http://www.historic.org.nz/Publications/HeritageNZMagazine/HeritageNz2009/HNZ0 9-WairauBar.aspx

McCarthy, C. and Bronwyn Labrum. 2005. "Museum studies and museums: Bringing together theory and practice.” Te Ara - Journal of Museums Aotearoa 30(2): 4-11

McCarthy, C. 2007. Exhibiting Maori: A history of colonial cultures of display. Wellington: Te Papa Press

_. 2011. Museums and Maori. Wellington: Te Papa Press

Neich, R., and Janet Davidson. 2004. Introduction to The Oldman Collection of Maori artifacts, by W.O. Oldman, vi-xxxv, Auckland: The Polynesian Society

One News. 2010. "Iwi face to face with 'Aunty."” Television New Zealand News, 4 April. Available at: http://tvnz.co.nz/national-news/iwi-face-aunty-3447101

Paterson, R. K. 2010. "Heading home: French law enables return of Māori heads to New Zealand.” International Journal of Cultural Property 17: 643-652

Patton, Q. 1990. Qualitative evaluation and research methods. Newbury Park, California: Sage publications

Peers, L. 2003. "Strands which refuse to be braided: Hair samples from Beatrice Blackwood's Ojibwe collection at the Pitt Rivers Museum.” Journal of material culture 8:75-96 
Peers, L and Alison K. Brown. 2003. Introduction to Museums and source communities: a Routledge reader, edited by Laura Peers and Alison K. Brown, 1-16. London: Routledge

Pickering, M. 2010. "Despatches from the front line? Museum experiences in applied repatriation." In The long way home: The meaning and values of repatriation, edited by Paul Turnbull and Michael Pickering, 163-174. New York: Berghahn Books

Reischek, A. Translated and edited by H.E.L. Priday. 1930. Yesterdays in Māoriland: New Zealand in the eighties. London: Jonathan Cape; facsimile edition, Auckland: Wilson and Horton, 1971.

Robley, H. R. 2003. Moko, or, Māori tattooing. New York: Dover. Originally published London: Chapman and Hall, 1896.

Sarantakos, S. 2005. Social Research ( $3^{\text {rd }}$ edition). Basingstoke: Palgrave MacMillan.

Sciolino, E. 2007. "French debate: Is Māori head body part or art?” The New York Times. 26 October 2007. Available at: http://www.nytimes.com/2007/10/26/world/europe/26france.html?scp=1\&sq=Māori\% 20head\&st=cse

Scott, E., and E.M. Luby. 2007. "Maintaining relationships with native communities: the role of museum management and governance." Museum management and curatorship 22(3): $265-285$

Simpson, M. G. 2001. Making representations: museums in the post-colonial era. New York: Routledge

Solomon, M. 2005. "The long journey home: Return of our ancestors." Paper presented to the World Archaeological Congress, Auckland, New Zealand, 12 November. 
Tahana, Y. 2011. "Māori head service full of French pomp." New Zealand Herald, May 10. Available at: http://www.nzherald.co.nz/nz/news/article.cfm?c_id=1\&objectid=10724531

Tapsell, P. 1998. “Taonga: A tribal response to museums.” PhD thesis, University of Oxford.

- 2005. "Out of sight, out of mind: Human remains at the Auckland Museum - Te Papa Whakahiku." In Looking reality in the eye: Museums and social responsibility, edited by Robert R. Janes and Gerald T. Conaty, 153-173. Calgary: University of Calgary Press

Taranaki Herald. 2007. "Maori catacombs: The caves at One-Tree Hill refuse from cannibal feasts." Taranaki Herald, 11 June.

Teague, L. S. 2007. "Respect for the dead, respect for the living." In Human remains: Guide for museums and academic institutions, edited by Vicky Cassman, Nancy Odegaard and Joseph Powell, 245-259. Lanham: AltaMira Press

Te Awekotuku, N., L.W. Nikora, M. Rua and R. Karapu. 2007. Mau moko: The world of Māori tattoo. Auckland: Penguin Publishing

Thompson, W. 2006. "Auckland War Memorial Museum to return Māori body parts.” New Zealand Herald, 27 February.

Turnbull, P., and Michael Pickering (eds.). 2010. The long way home: The meaning and values of repatriation. New York: Berghahn Books

Walker, S., Anaru Eketone, Anita Gibbs. 2006. “An exploration of kaupapa Maori research, its principles, processes and applications." International Journal of Social Research Methodology, 9(4): 331-344

Wilkinson, T.M. 2001. "The core ideas of research ethics.” In Research ethics in Aotearoa New Zealand: Concepts, Practice, Critique, ed. M Tolich, 13-24. Auckland: Longman 
Wilson, C. 2009. "Implications and challenges of repatriating and reburying Ngarrindjeri Old People from the 'Edinburgh Collection'." Museum International 61(1-2): 37-40 